\title{
CANADIAN NEWSPRINT PORTRAYALS OF FOREIGN BRIDES/ "MAIL ORDER BRIDES": COMPARING REPRESENTATIONS SURROUNDING POLICY CHANGES IN 2002 AND 2012
}

\author{
by
}

Deanna Louise Santuccio, BA, University of Ontario Institute of Technology, 2015

\author{
A Major Research Paper \\ presented to Ryerson University \\ in partial fulfillment of the requirements for the degree of \\ Master of Arts \\ in the Program of \\ Immigration and Settlement Studies
}

Toronto, Ontario, Canada, 2016

(C) Deanna Louise Santuccio 2016 


\section{Author's Declaration}

I hereby declare that I am the sole author of this Major Research Paper. This is a true copy of the MRP, including any required final revisions, as accepted by my examiners.

I authorize Ryerson University to lend this MRP to other institutions or individuals for the purpose of scholarly research.

I further authorize Ryerson University to reproduce this MRP by photocopying or by other means, in total or in part, at the request of other institutions or individuals for the purpose of scholarly research.

I understand that my MRP may be made electronically available to the public.

Deanna Louise Santuccio 


\title{
Canadian Newsprint Portrayals of Foreign Brides/ "Mail Order Brides": Comparing
}

Representations Surrounding Policy Changes in 2002 and 2012

\author{
Deanna Louise Santuccio \\ Master of Arts 2016 \\ Immigration and Settlement Studies \\ Ryerson University
}

\begin{abstract}
Despite the small amount of Canadian literature on the topic of "mail order brides", authors have argued that women in this situation often face abuse at a heightened rate, which highlights the need for more research. Focusing on the time periods of 2000-2004 and 20102014, Canadian newsprint stories were gathered in order to compare media portrayals of "mail order brides" surrounding two important policy changes. Findings indicate that surrounding a policy amendment in 2002, more positive portrayals of "mail order brides" can be noted, whereas more emphasis on fraudulent cases of "mail order brides" are present in press surrounding a second policy change in 2012. As well, blaming the individual is constant over both time periods, with minimal focus on broader structural issues that disadvantage "mail order brides". Future research is needed to expand understanding on this topic with the goal of promoting more progressive immigration policies.
\end{abstract}

Keywords: “mail order brides", immigrant women, domestic violence/abuse, structural inequalities, policy change 


\section{Acknowledgments}

I wish to first extend thanks to my supervisor Dr. Patrizia Albanese for all her help through the MRP process; from planning deadlines and reviewing my written work, to helping me maintain a positive attitude in every stage, Dr. Albanese has supported me to produce the best final product possible. I would also like to thank Dr. Sedef Arat-Koç, my second reader, for taking the time to offer any final suggestions regarding revision. My progress through postsecondary education to this point would not have been possible without the support from my family; the numerous hours my mum has spent listening to my essays, presentation preparation and ideas has helped me succeed while pursuing this degree. Finally, I would like to thank my

significant other, Justin, as well as my best friend, Meygan, for all their encouragement through the entire program, including helping me maintain balance in my life.

My sincerest appreciation to you all. 


\section{Table of Contents}

Author's Declaration..................................................................... ii

Abstract.......................................................................................... iii

Acknowledgements....................................................................... iv

Table of Contents...................................................................... v

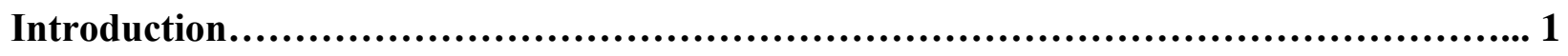

Background, Context and Review of Literature........................................ 3

"Mail Order Bride" Defined ....................................................... 3

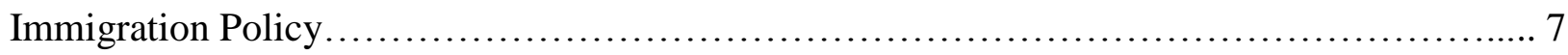

Numbers and Trends/Prevalence.................................................. 10

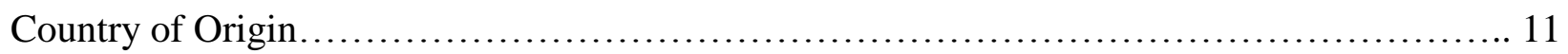

Causes...................................................................... 12

Technological Advancement............................................... 12

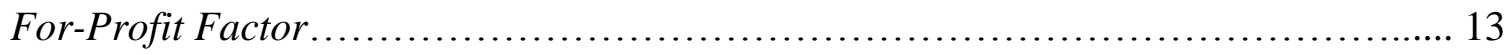

Patriarchy and its Connection to the "Mail Order Bride" Phenomenon.................. 13

Poverty among "Mail Order Brides" ........................................ 15

Domestic Abuse................................................................ 16

Economic Inequality and Increased Potential for Abuse............................... 19

Importance of Studying Media.......................................................... 21

Author's Social Location................................................................. 23

Theoretical Framework................................................................ 24

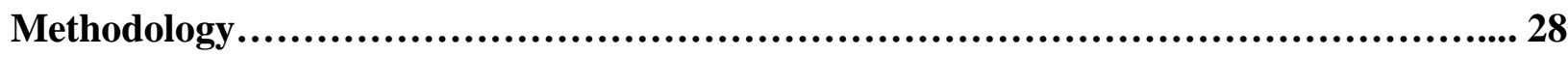

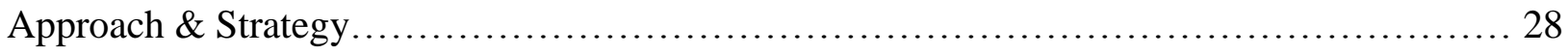




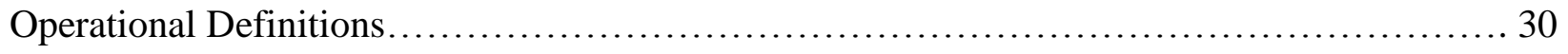

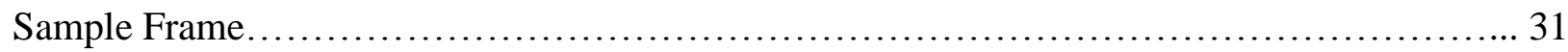

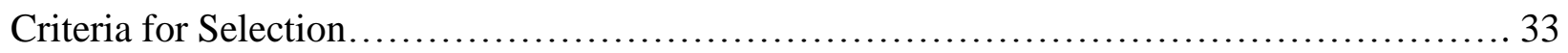

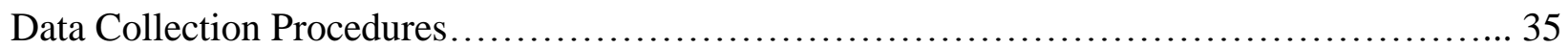

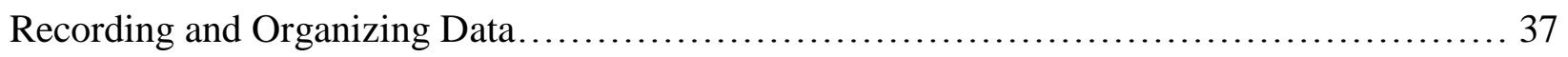

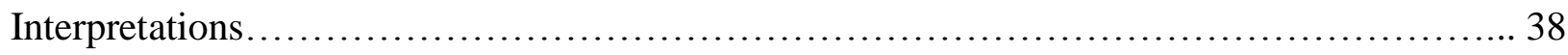

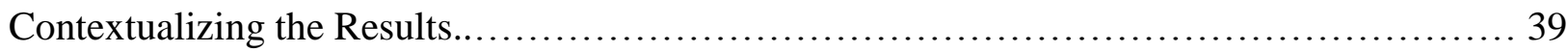

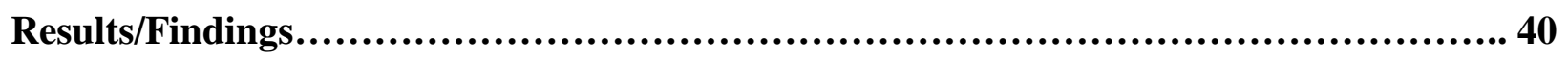

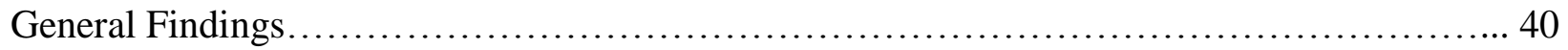

Mention of Policy Flaws in Stories...................................................... 41

The Presence and Subjects of Blame in News Coverage..................................... 43

The Use of "Fraud" and Who it is Directed Toward......................................... 45

Connections between "Mail Order Brides" and Human Trafficking .......................... 49

Reporting on "Mail Order Brides” and/or Western Women as 'Traditional' ..................... 51

Discussion of Domestic Violence/Abuse in the Stories.................................... 53

The Narrative of "Choice" in Newspaper Coverage .......................................... 55

References to Social/Structural Inequalities........................................... 57

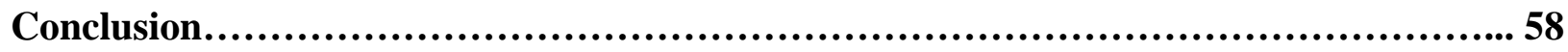

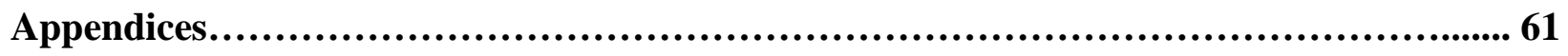

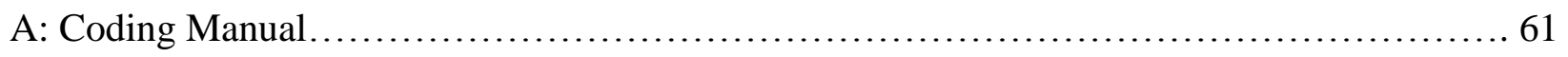

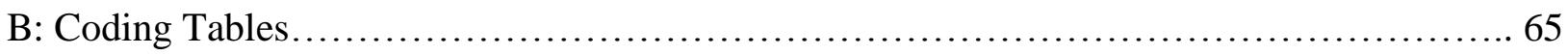

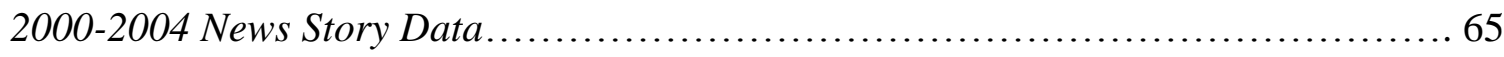

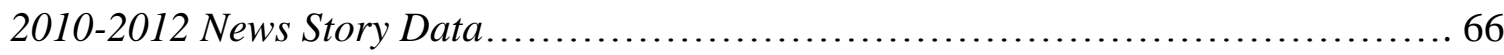




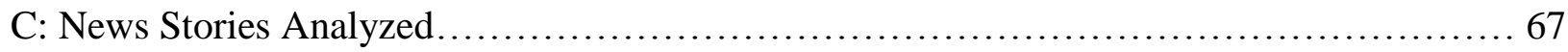

References......................................................................................... 74 


\section{Introduction}

Through technological advancements, information is shared globally and networks forged despite individuals being continents apart. While this is not new, technology has facilitated making connections across the globe that enabled men to seek more traditional relationships through transnational marriages (Belleau, 2000B). While women are also able to seek partners transnationally, I am specifically interested in understanding the phenomenon of traditionallyoriented heterosexual men selecting brides aboard. I believe this has much to do with a reflection and reinforcement of patriarchal values. To curb notions of potential bias, there are a multitude of agencies advertising women as available commodities in contrast to the few agencies that market foreign men (Lloyd, 2000). These technological advancements have afforded men in Canada the ability to select a wife from the comfort of their home, much like shopping for a commodity online. The facilitation of marriage through channels such as the internet, creates unfavourable implications when linked with Canadian immigration policies. These policies are in place largely to combat the potential for fraudulent marriage, with less of an immediate focus on the protection of "mail order brides" (Citizenship and Immigration Canada, 2016c).

The antiquated notion of the "mail order bride" has not disappeared. In fact, it has been revived by the widespread use of the Internet and the persistence of flawed immigration policies that make some migrant women more vulnerable. Canada has incorporated policies that attempt to eliminate dependency (like the reduction from ten to three year sponsorship requirement). However, under the conservative government in 2012, Canada reinstated provisions that are detrimental to the safety of "mail order brides". The implementation of conditional permanent residency forces women into potentially abusive situations for two years if they want to maintain secure status within Canada (Citizenship and Immigration Canada, 2014). 
The aforementioned policy flaws need to be addressed because of the potential for abuse of women who arrive as "mail order brides". While the prevalence of abuse via scholarly literature is not precise in terms of "mail order brides" specifically, it is approximated that immigrant women and "mail order brides" alike face domestic violence three to six times more than the Canadian born population (Grosh, 2011; Kusel, 2014). "Mail order brides" face more onerous policies, like the aforementioned conditional permanent residency, than other immigrant women. Thus, it can be argued that "mail order brides" are a subset of immigrant women who face heightened risk due to the forced dependency for prolonged periods on their male counterparts.

The research problem of flawed immigration policy surrounding "mail order brides" leading to heightened risk of abuse because of their lack of independence, is an important area that requires attention. The first reason why a study should be conducted on "mail order brides" is because of the limited existing research on this topic. Also, of the limited number of authors publishing in this area, even fewer specifically focus on the Canadian context and experience of "mail order brides". Furthermore, due to the articles that reference heightened abuse of "mail order brides", it is clear that further contemporary research that is relevant to Canada needs to be conducted. Through added research on the topic of "mail order brides" it may be possible to advocate for policy change that will afford "mail order brides" more protection. By eliminating sanctions that will further their dependence on their male counterparts, the heightened prevalence of abuse may lessen. 


\section{Background, Context and Review of Literature}

\section{"Mail Order Bride" Defined}

Selection of the term "mail order bride", as opposed to the neutral term "marriage migration", serves a particular purpose. Through the literature I have researched on the topic of “mail order brides", it would be wholly unrealistic to portray neutrality within a phenomenon that is laden with commodification of women and patriarchy. Patriarchy refers to global social structures that are in existence to oppress women (Offen, 1988). Rather than following the work of Chaudhuri et al. (2014), which encompasses neutrality then contextualization, I would prefer to exemplify the phenomenon as bound to unequal power and gender relations (Belleau, 2003B). My intent is not to dehumanize these women, but instead underscore the process of commodification and the systemic issues. For this project I would like to evoke unsettling emotion, so that future work may be undertaken that begins to humanize this process with the voices of the brides included.

The term "mail order bride" is not new (Liu, 2015; Newsome, 2007). Historically, men would choose their bride through the use of tangible photographs as well as the exchange of mailed letters. Ergo, the inception of the term "mail order bride" originated from the very fact that postal mail was utilised to make contact with potential brides (Liu, 2015). While technological advancements have changed the method of connecting to prospective brides, the end goal of acquiring a bride - often of a different cultural background - is constant (Belleau, 2000B). The inclusion of bride in the term as opposed to something gender neutral is indicative of who is 'mailed in' more frequently through this phenomenon. While men, too, can be commodified through the "mail-order" industry, it occurs at a much lower frequency. Therefore, 
"mail order bride" has been utilized to signify the overrepresentation of women being commodified within this industry (Lloyd, 2000).

The term marriage migration has also been used to denote "mail order brides" (Constable, 2012). The use of marriage migration in place of "mail order bride" is to highlight the transnational aspect of the phenomenon (Belleau, 2003B). While "mail order bride" focuses in on the commodification of women specifically (Belleau, 2003B), marriage migration appears to be utilised as a more gender and power neutral approach. For example, when used by Chaudhuri et al. (2014), the neutrality of marriage migration is then contextualized by a patriarchal framework within a study of domestic violence. Similarly, Constable (2012) utilizes marriage migration as a keyword in order to signify the general purpose of her research, while identifying 'foreign brides' throughout as the main focus.

"Mail order bride" is used in connection with International Marriage Brokerages (IMBs), human trafficking, as well as forced marriages. Primarily, IMBs are a new and emerging tool used to connect men with potential brides transnationally. They are privatized organizations that act as matchmakers to allow predominately 'western' men to find a bride in another country (Constable, 2012; Newsome, 2007). The internet has inflated the use of IMBs due to easy and efficient accessibility to women from around the world. IMBs potential connection to heightened incidences in human trafficking and domestic violence is an immense concern (Constable, 2012; Newsome, 2007). Further discussion on problematizing IMBs will occur at a later point within the literature review.

There have been some connections made between "mail order brides" and human trafficking. For example, both involve groups of women who have been accused of deception and coercion (Constable, 2013; Newsome, 2007). The definition of human trafficking elaborates 
that in order for something to be considered trafficking, there must be an element of deception and/or coercion. Human trafficking is conflated with numerous different phenomenon inclusive of "mail order brides"; this conflation is often used to serve the interests of a particular group (Hussein, 2015). An example will be provided below.

As aforementioned, some "mail order brides" immigrate to Canada with the assistance of IMBs. Newsome (2007) and the United Nations (2010) note that IMBs are linked to trafficking, due to the processes associated. The information "mail order brides" receive about potential husbands may be falsified. Therefore, the element of deception which signifies potential trafficking can be connected to IMBs (Newsome, 2007; United Nations, 2010). Since the IMBs facilitate the meeting between husbands and "mail order brides", the potential for deception in the process, specifically in terms of Canada, may link the "mail order bride" industry to trafficking. The implementation of the International Marriage Brokerage Act (IMBRA) in the United States attempts to lessen the potential for deception by making the disclosure of the husbands records to the potential "mail order bride" mandatory - inclusive of criminal record, and marital history (Newsome, 2007; United Nations, 2010)

As Constable (2012) has argued, the association between human trafficking and "mail order brides" serves the purpose of greater governmental control over women as well as over national borders; in the case of "mail order brides", this is achieved by the implementation of policy that restricts marriages. As an example of policy restrictions, while IMBRA was enacted to protect women from being trafficked, Constable (2012) notes that it is not effective in protecting women from being trafficked, especially because not all husband and "mail order bride" relationships are formed through IMBs. Other authors, like Newsome (2007) and the 
United Nations (2010) argue that IMBRA is an effective measure, simply because part of the "mail order bride" population is aided by IMBs.

Historically, and in most cases contemporarily, a "mail order bride" will only be able to access information that the husband wants her to know. Grievous power imbalances exist, especially because it is often the husband funding the process (Newsome, 2007). There is argument that the phenomenon of "mail order brides" as a whole should be considered trafficking due to the power imbalances associated with the forced servitude a bride may experience once she has arrived in the home of her husband (Newsome, 2007). Often, once a woman becomes a "mail order bride", she becomes indebted to her husband and is unable to remove herself from a potentially negative environment due to many constraints. The inability to alter or remove oneself from a coercive, exploitative, and/or violent situation is recognized as being trafficked (Lloyd, 2000). Ergo, "The mail order bride industry is one of the most open forms of trafficking women into developed nations” (Lloyd, 2000, p. 344).

Forced marriage has also been used to denote "mail order brides". While forced marriages can take on many forms, Alanen (2016) indicates that the circumstances in a "mail order brides" country of origin can force her into transnational marriage. Duress is a key indicator to decipher whether a marriage is forced or not; even when a "mail order bride" consents to marriage, the consent may not be free. Common methods of force include phrases that indicate potential harm to the individual or family members if one does not become a "mail order bride" (Alanen, 2016).

Through my research, the term "mail order bride" will be used to refer to women from outside of Canada that market themselves via online forums for the purpose of attaining a Canadian husband. The process of her being selected by a Canadian man and moving to Canada 
on a sponsorship visa is what gives her the status of a "mail order bride". The term "mail order bride" is not only a label, but the process of selection and emigration from one's country of origin into Canada (for this project, these women do not necessarily have to have used IMBs).

\section{Immigration Policy}

The United States has specific legislation and policy surrounding “mail order brides". In the United States, there is the K-1 visa which allows a potential spouse entrance into the country for a total of 90 days. In that 90 days, the couple must decide if the relationship is going to work and consequently marry or the visa holder must return to their country of origin. If the couple decides to marry, the K-1 visa becomes a conditional residency which can arguably be considered a precarious state prior to becoming a permanent resident. Conditional residency simply means that for a two year period following the expiry of the K-1 visa, the partner who holds citizenship or permeant resident status is responsible for their foreign spouse (Belleau, 2003B; Grosh, 2011). Therefore, in the case of the United States, the "mail order bride" holds no rights associated with residency for a total of two years and ninety days - longer if backlogs ensue.

In contrast to the United States, Canada does not have specific legislation pertaining to “mail order brides". Previously, Canada utilised a fiancée visa, which was similar to the K-1 visa in the United States. The use of the fiancée visa was abolished in 2002 and simple sponsorship was introduced. The purpose was to hinder the rush and demand of the 'marry in 90 days or else' (Belleau, 2003A; Belleau, 2003B). The required sponsorship period was also reduced from ten years to three years in order to limit the dependence the "mail order bride" has on her husband (Belleau, 2003A; Belleau, 2003B; Immigration and Refugee Protection Regulations, 2002). Sponsored individuals were granted permanent residency upon arrival to Canada. The sponsor 
signs an unconditional undertaking which means that they are responsible for their partner for a total of three years. The sponsor must ensure that their partner is provided with all necessities, inclusive of shelter, food, clothing and utilities (Citizenship and Immigration Canada, 2016b).

While the reduction in sponsorship period was a positive advancement for the protection of "mail order brides", in October of 2012, under the conservative government, a new policy was implemented that fosters detriment to the sponsored spouse due to the fear of marriage fraud as well as marriages of convenience (Citizenship and Immigration Canada, 2012). Rather than being eligible for permanent residency immediately upon arrival to Canada, sponsored individuals are now solely eligible for conditional permanent residency if they have been in a relationship with the sponsor for two years or less; to be subject to conditional permanent residency, the couple must not have any children in common (Citizenship and Immigration Canada, 2012; Citizenship and Immigration Canada, 2014). Conditional permanent residency creates the requirement of the couple to live together for two years in order to prove the legitimacy of their relationship (Citizenship and Immigration Canada, 2012; Citizenship and Immigration Canada, 2014). Now, not only does the three year sponsorship period remain, but two years of the three year undertaking includes forced cohabitation between the "mail order bride" and her husband. This new implementation is onerous on "mail order brides" because it disallows the opportunity to remove themselves from potentially abusive relationships without repercussions to their status.

The aforementioned fear of marriage fraud and marriages of convenience is proliferated by the government. Citizenship and Immigration Canada (2016c) offers an entire page with a focus on marriage fraud. The information reads as a warning, emphasising that careful thought is needed prior to making the decision to sponsor a "mail order bride" (Citizenship and 
Immigration Canada, 2012; Citizenship and Immigration Canada, 2016c). Legitimate and illegitimate are also buzzwords utilised in the place of fraud throughout the discussion of sponsoring a foreign partner (Citizenship and Immigration Canada, 2014). Similarly, scholarly literature points to fraud as the government's main concern. Specifically in the United States, Lloyd (2000) and Narayan (1995) express that the government's focus on marriage fraud has led to minimal protections for "mail order brides". Alteration of policy surrounding "mail order bride" sponsorship has been in direct response to uncovering fraudulent cases, rather than creating autonomy for the newly arrived bride (Narayan, 1995).

Questions surrounding the emergence of conditional residency in Canada point to many aggravating realizations. On the part of Canada, the reduction in sponsorship from ten years to three years was an advancement (Belleau, 2003A; Belleau, 2003B; Immigration and Refugee Protection Regulations, 2002); however, the implementation of conditional permanent residency in 2012 again adds more dependence for the "mail order brides". The inclusion of conditional permanent residency may endanger "mail order brides" since they may remain in violent/abusive relationships in order to gain citizenship.

Due to the differences in policies between Canada and the United States, generalizations cannot be made for "mail order brides" in Canada based on data from the United States. There is much more research pertaining to the United States, with few sources other than governmental focusing on Canada. In order to mend policy flaws, there needs to be some form of public acknowledgment and a pressure to move towards alternate options. Therefore, in order to push policy to eliminate power imbalances in the relationships between "mail order brides" and their spouses, it is essential that public perception (which will be discussed in depth at a later point) is understood, analyzed and potentially reconfigured. 


\section{Numbers and Trends/Prevalence}

Through my research, I was unable to find international estimates of the prevalence of the "mail order bride" phenomenon. The scholarly literature is limited as there are minimal wide scope studies; most of the literature focuses on specific geographic locations. As for the United States, many estimates were reported. Specifically in terms of "mail order brides" coming from the Philippines into the United States, there is an estimate of 4000 brides entering yearly (Lloyd, 2000). So (2006) reported similar numbers, with an estimated 4000-6000 "mail order brides" entering the United States in a single year - 1988; however, this was the total estimate, as opposed to an estimate from one specific country of origin (So, 2006). On the lower end of estimations, Narayan (1995) states that, per year, 2000-3500 men from the United States bring foreign wives to marry from a multitude of origins. As a grand total, it is estimated that 9,500 to 14,500 females and males enter the United States on fiancée visas annually (Newsome, 2007).

The prevalence of "mail order brides" coming to the United States was mentioned in numerous articles, however Canadian estimates were not reviewed in any article. Through analysis of the United States estimates, it appears the most dated sources provide low estimates, such as Narayan (1995), reporting only 2000 to 3500 "mail order brides" arrive yearly. In stark contrast, a more recent estimate by Newsome (2007) shows that a total of 14,500 men and women on fiancée visas may be entering the United States yearly- solely based on IMBs. Kusel (2014) supports this finding, as she states that there are more than 14,000 women who enter the United States hoping to marry. These findings were also based on the use of IMB online sites in order to become acquainted (Kusel, 2014). Therefore, these statistics may also fall short, since not all relationships will begin through the use of IMBs. 
When analyzing a phenomenon, it is important to know and express the rate of occurrence. Finding flaws in a process that is minimally utilized is not in need of urgent amendment, arguably. However, when a process is to the detriment of a large group of people, its negative impacts warrant urgent attention and resolve. Therefore, in light of the lack of detail regarding the prevalence of "mail order brides", specifically in the Canadian context, new studies are needed to prompt attention.

\section{Country of Origin}

The inflated focus on the United States can be attributed to its standings as a top import country. The United States intakes the most "mail order brides" internationally (Lloyd, 2000). Information gathered from the United Nations (2010) also highlights that the United States is a main country of destination. "Mail order brides" come to the United States from numerous export regions/countries; these women can come from Europe (generally eastern), Russia, countries of the post-Soviet Union, Asia (particularly south) as well as Central America (Lloyd, 2000). The number one export country is the Philippines (Lloyd, 2000; Newsome, 2007; United Nations, 2010). It is estimated that there are 20,000 "mail order brides" leaving the Philippines yearly to unite with foreign partners (Lloyd, 2000).

Newsome (2007) and So (2006) note that IMBs advertise women from the former Soviet Union. Similarly, it is thought that women from countries that are part of the former Soviet Union are favoured due to their 'whiteness'. Thus, if many women from Russia, Latvia, etc., that make up the former Soviet Union are available, then they will be favoured over Asian women (Narayan, 1995). Both Narayan (1995) and So (2006) outline that for this very reason, women from Africa are not readily advertised, nor available, due to the preference of "white" women. 
Many of the articles on "mail order brides" focus on the migrating women's countries of origin. Specific examples of how each country of origin contributes to the "mail order bride" phenomenon will be discussed next in the 'Causes' section. The emphasis on country of origin allows for minimal generalizations since women from different countries have varied experiences; however, they provide insight on the economic and social conditions that lead some women to consider this option when it comes to migration.

\section{Causes}

\section{Technological Advancement.}

Many studies ascertain that a general increase of prevalence in this phenomenon is due to technological advancement (Belleau, 2003B; Kusel, 2014; Merriman, 2012). Due to the widespread use of the Internet, geographical locations separated by large bodies of water become connected. In a globalized world, commodities offered anywhere in Asia, for example, are available to Canadians and Americans without leaving the comfort of their homes. Not only have commodities become easily attainable, but communication via fast paced channels have become prominent (Kusel, 2014; Merriman 2012). No longer is there a lengthy wait for written letters, but instead instantaneous responses are possible due to e-mail, chat rooms and other social media (Kusel, 2014).

The ability to easily network with individuals across the globe has led to individuals seeking marriage from outside of their immediate communities (Belleau, 2003B). While technological advancement has assisted in the ability for individuals looking for international and intercultural relationships, these tasks are often not undertaken alone. Many of those seeking brides from across the globe employ the assistance of IMBs. The most prominent users of IMBs are men from Canada, the United States, and Australia (Kusel, 2014; Grosh, 2011). 


\section{For-Profit Factor.}

Constable (2012), Kusel (2014), Liu (2015) and Newsome (2007) point to the for-profit aspect of IMBs. Newsome (2007) highlights the 'profit first' process with a story of IMB operators urging a "mail order bride" to stay with her abusive husband. Thus, capitalism, or 'profit-first' ideologies facilitate the rise of the IMB industry (Constable, 2012; Newsome, 2007). This industry, like many others, is increasingly popular due to the possibility of economic gain for private companies. I argue that this has a lot to do with the global neoliberal climate that has contributed to the prevalence of "mail order brides"- something that should be taken up in more detail in future research in this area. Further discussion on the role of economics and its link to neoliberalism can be found below.

\section{Patriarchy and its Connection to the "Mail Order Bride" Phenomenon.}

A catalyst for both forced marriage and the "mail order bride" phenomenon is the desire to control women - whether that be controlling sexuality, behaviour, or attainment of freedom (Alanen, 2016). Again, patriarchy is defined as the infusion of male dominance in social structures that both oppresses and subordinates women (Offen, 1988). Through male dominance, gender roles are in place and inequalities exist which place men above women as their superiors (Connell \& Messerschmidt, 2005). Chaudhuri et al. (2014) speak to the patriarchal climate of a "mail order brides" country of origin. They include an example of South Asia, where women are not afforded the same protections as they are in the United States. Thus, in order to escape abuse, women become "mail order brides". Patriarchy, which was infused in their culture, was a push factor to migrate for purposes of marriage (Chaudhuri et al., 2014).

Another set of authors focus on the Philippines and there is mention of gender roles that disadvantage women. Due to patriarchy, women are not welcomed into the economic sector 
(Lloyd, 2000; Newsome, 2007). Russia is also given as an example of patriarchy which mirrors the experiences of women in the Philippines. Similar to Southeast Asian culture, women's social status plays an immense role in a woman's decision to become a "mail order bride" (Narayan, 1995; Newsome, 2007).

In association with patriarchy, another important view that requires analysis is that of the men who decide to seek a bride abroad in this way (the men of the receiving country). A common pattern noted within scholarly writing, is that we have seen a rise in the popularity of "mail order brides" in direct response to increased feminism (Belleau, 2003B; Chaudhuri et al., 2014; Lloyd, 2000; Narayan, 1995; Newsome, 2007; So, 2006). The argument runs as follows: with the rise of feminism in Canada and the United States, many traditional/patriarchal men have turned to the internet to find traditional (dependent as opposed to independent) women abroad (Lloyd, 2000; Newsome, 2007; So, 2006). The assumption is that "western women" are too liberated and independent to appeal to these men (Lloyd, 2000; Miteva, 2006; Narayan, 1995). In contrast, women who come from less prosperous countries are perceived to be more family oriented and are often more economically dependent; thus, these women may be more willing to consider a life that could involve a kind of servitude to a foreign man (Belleau, 2003B; Kusel, 2014).

While some have made arguments like the ones above, little critical analysis has been done on the views expressed by those seeking women abroad. Men who seek "mail order brides" are interested in traditional wives (Newsome, 2007; So 2006); however, the authors fail to describe what is meant by or desired in a traditional woman. What really underlies tradition is cultural and structural inability to gain independence. These males, then, are seeking women who 
are not afforded similar opportunities that western women attain, which furthers their subordination and dependency (Belleau, 2003B; Grosh, 2011; Narayan, 1995).

\section{Poverty among "Mail Order Brides".}

The above discussion of the cultural infusion of patriarchy is the basis on which women become impoverished. Alanen (2016), Narayan (1995) and Newsome (2007) state that poverty can be a factor that creates forced marriage and the "mail order bride" phenomenon. The inability to survive in ones country of origin due to being destitute can leave a women with no other option but to become a "mail order bride". To provide an example of critics, authors Langevin and Belleau (2000) as well as Hodges (2010) do acknowledge that "mail order brides" are often impoverished, but they question why there is a lack of inclusion of love as a personal motivation. The fact that the economic conditions are unfavourable does not eliminate the potential for personal motives, like love, to be a part of the decision making process when becoming a "mail order bride" (Hodges, 2010; Langevin \& Belleau, 2000).

Lloyd (2000) found that women from the Philippines choose to migrate as a "mail order brides" because their limited options include becoming a sex trade worker or becoming part of the migrant labour stream. Unemployment for women is rampant, as women are not welcomed into the economic sector, as mentioned above (Lloyd, 2000; Newsome, 2007). A woman may be unable to better her financial situation, unless she turns to informal work - such as the sex trade. The unfavourable choices present may act as a factor in forcing women into choosing the path of a "mail order bride" (Lloyd, 2000). A rise in "mail order brides" from Russia is thought to be catalyzed by similar factors. Post-communist transformation in Eastern-Europe led to a decrease in social services and an increase in poverty (Miteva, 2006; Narayan, 1995). Overall, "mail order brides" are described as young and exceedingly impoverished (Narayan, 1995). 


\section{Domestic Abuse}

It has been expressed that the policy in both Canada and the United States is not wholly protective of "mail order brides" (Belleau, 2003B; Grosh, 2011). The skepticism about marrying for love that surrounds "mail order brides" within immigration law inhibits progression to protective legislation; security against women seeking marriages in the Canada and the United States for purposes of gaining citizenship is the focus of immigration laws (Citizenship and Immigration Canada, 2012; Citizenship and Immigration Canada, 2016c; Grosh, 2011; Lloyd, 2000). Abuse toward "mail order brides" is a topic that is often overlooked and rarely debated, however, in the United States, "mail order brides" are three to six times more likely to experience domestic violence (Grosh, 2011). Newsome (2007) and Narayan (1995) state that $77 \%$ of immigrant women who a hold status which makes them dependent on a sponsor, suffer abuse. Of the immigrant women who seek assistance for battery, half met their spouse through IMBs (Grosh, 2011; Kusel, 2014).

While the estimates of domestic abuse cited by Grosh (2011) and Kusel (2014) may lack some credibility because the information was gathered through the Tahirih Justice Centre (2009), a not-for-profit organization, it nonetheless gives us a sense of what may be going on. Tahirih Justice Centre (2009) explains that these increased probabilities were extrapolated from the work of another group of authors, Aguilar-Hass, Ammar and Orloff (2006). Aguilar-Hass, Ammar and Orloff (2006) found that immigrant women in the United States are susceptible to higher rates of domestic violence than American-born women. The claim that "mail order brides" face similar rates of domestic violence as other immigrant women cannot be confirmed; however, their dependence on their male sponsors via specific immigration policy certainly makes them significantly more vulnerable than other women. That is, not all immigrant women encounter 
similar policies that enforce conditional residency for a certain amount of years, which is what makes "mail order brides" especially dependent. Therefore, further research must be conducted on the topic of "mail order brides" specifically, in order to confidently comment on the prevalence of domestic violence.

Merriman (2012) contradicts the speculations and estimates above, noting that for the most part, we have only been witness to a few sensationalized cases of abuse of "mail order brides" that have hit the media. Constable (2012) also provides similar argumentation, where there are no solid statistics that speak to increased abuse. Similarly, there is said to be little evidence that the "mail order bride" phenomenon and use of IMBs inflate the occurrences of human trafficking (Constable, 2012). Constable (2012) argues that IMBRA is yet another implementation to control boarders, women and society's perception of what constitutes a valid relationship. However, one cannot dismiss the fact that, in many ways, "mail order brides" are entering into relationships in which they may become exceedingly dependent, especially due to immigration policy.

Grosh (2011) and Kusel (2014) counter these arguments by claiming that current statistics and estimates likely underestimate the true extent of the problem because of the privatization of domestic life, especially among those who embrace a traditional view of family. Grosh (2011) and Kusel (2014) do offer findings that portray the existence of unequal relationships between "mail order brides" and their male partners, thus that could be indicative of increased domestic violence; although, more reliable research is needed in this area. The 'choice' rhetoric, also proposed by Merriman (2012) is inherently flawed, as "mail order brides" often $d o$ not have a choice to leave their home country since they are often economically disadvantaged. 
Canada does provide some protections to "mail order brides". If domestic abuse or neglect can be proven, a "mail order bride" does not have to remain living with the abuser for two years (Citizenship and Immigration Canada, 2012; Citizenship and Immigration Canada, 2014). The sponsor of the "mail order bride" usually must support an application for permanent residency; however in a case of domestic violence the Immigration and Refugee Protection Act (2001) allows exemption so that "mail order brides" can petition for themselves (United Nations, 2010). Also, individuals with criminal records have a family sponsorship ban; thus one cannot sponsor a "mail order bride" if they have a criminal conviction (Citizenship and Immigration Canada, 2016a). While Canada does offer these protections to "mail order brides" after their arrival, there are no preventative strategies incorporated prior to their arrival.

In contrast to Canada, the United States does offer much more preventative safeguards. Under the Violence Against Women Act (VAWA), the United States affords "mail order brides" the ability to self-petition for permanent residency after the cessation of the K-1 visa. In addition, the United States has made policy to combat the negative effects of the IMBs (United Nations, 2010). The International Marriage Broker Regulation Act (IMBRA) of 2005 requires that "mail order brides" are provided with information on the sponsor, like criminal history, marital history as well as domestic violence protection information in her language (Constable, 2012; Newsome, 2007; United Nations, 2010). For Canada, which is without IMBRA, "mail order brides" only receive information that the husband wants to provide, whether it be truth or lies (Newsome, 2007). Ergo, IMBRA has allowed the United States to provide more protection for "mail order brides" and exceed Canada's protection capabilities. 


\section{Global Economic Inequalities and the Increased Potential for Abuse}

Globalization and neoliberalism play a part in exploiting the countries in the global south to the benefit of the global north; thus the "mail order bride" industry capitalizes on the misfortune of the global south (Lloyd, 2000). The competitive nature of a capitalist society has created immense inequalities. These inequalities have led to the devaluation of certain groups of people, arguably disadvantaging the majority of those within the global south. The immense exploitation of the global south and the restrictive policies on these individuals' immigration to Canada specifically, exacerbates their oppressed and devalued position. These restrictive policies come in the form of securitization enacted by the state (Giroux, 2008; Young, 2007). A prime example of securitization discourse in connection to "mail order brides" is the moral panic surrounding fraudulent marriages (Citizenship and Immigration Canada, 2012). Constable (2006) and Hodges (2010) argue that the connection between "mail order brides" and human trafficking propels the promotion of these restrictive immigration policies. Framing "mail order brides" as something that Canadian citizens require protection from may leave these women no choice but to stay in their home countries, or find more other means to advance their economic position, which be discussed below.

This trend has resulted in an immense influx of individuals from the global south searching for economic opportunities abroad. As an example, women seek out forms of domestic labour to provide for themselves and their family. However, the chance to move abroad for domestic labour does not solve the inequality women are experiencing. As Arat-Koç (1989) mentions, the inclusion of women into the domestic labour force through live-in caregiver positons, for example, does not provide a solution to inequality. Rather, the position remains devalued, with racial and class intersections added (Arat-Koç, 1989). Thus, the option of 
becoming a "mail order bride" may appear to be a better alternative as opposed to manual, devalued labour. "Mail order brides" are often from destitute regions, searching for freedom from the tumultuous economic conditions (Belleau, 2003A; Belleau, 2003B; Grosh, 2011; Zare \& Mendoza, 2011).

According to Canadian research, our immigration laws paired with the global acceptance of hegemonic masculinity, creates an environment where women are unable to thrive (Belleau, 2003A). Often women from the global south are not afforded the same abilities as men to travel to the global north, specifically due to their lower status and lack of economic resources (Belleau, 2003A; Lloyd, 2000; Narayan, 1995; Newsome, 2007). Women in a global context but especially within some parts of the global south - are often not given rights to land ownership, higher education, or job opportunities (Belleau, 2003A; Lloyd, 2000). Thus, with limited job opportunities and no rights to ownership, some women must find a way to improve their impoverished state. Through Canada's current immigration system one must acquire enough points; however, without education and potentially no command of either English or French, most are unable to attain the required points. Thus, for some, marriage is the only option to escape the detrimental effects of neoliberalism (Belleau, 2003A).

Merriman (2012), who underplayed the challenges experienced by "mail order brides", has failed to take into account the effects of neoliberalism and the immense inequalities between the southern and the northern hemispheres. Merriman's (2012) assumption about women having choice lacks contextualization. Similarly, his argument that these women have a choice and free will to become "mail order brides" does not allow for a comprehensive analysis of structural push factors that drive women to become "mail order brides". He posits that the ability for women to become "mail order brides" allows them a safe way out of their destitute conditions 
(Merriman, 2012). However, it is not only domestic violence that "mail order brides" face, but also economic abuse. Due to the dependence the "mail order bride" has on her husband prior to acquiring permanent residency, she may endure monetary and mobility restrictions - abiding by the rules of a potentially controlling partner (Belleau, 2003B; Grosh, 2011; Kusel, 2011).

The ability for women to be commodified connects to the work of Belleau (2003B); a "mail order bride's" position in society is reflective of more global issues such as sexism, hegemonic masculinity and patriarchy (Belleau, 2003B). Many of the articles fell short in establishing a focus on more structural issues associated with the difficulties "mail order brides" face in terms of gaining independence. While there is focus on policy flaws as well as the fact that IMBs are extremely exploitative, there is little attention paid to the effects of neoliberalism or patriarchy. For example, Grosh (2011) and Kusel (2014) highlight that the IMB is the root cause of the issues "mail order brides" face. These authors failed to keep in mind that none of these flaws or exploitation would be possible unless the infusion of patriarchy allowed and welcomed the commodification of women (Belleau, 2003B; Chaudhuri et al., 2014).

\section{Importance of Studying Media}

Due to so little knowledge about "mail order brides" in Canada, it is pertinent to begin by unpacking where Canadians gain their information on the topic. The media provides information on numerous topics, even representations of "mail order brides". In order to potentially push for amendment of Canada's immigration policy affecting "mail order brides", it is imperative that information is gathered on how these women are represented within the media. In light of the moral panic on the topic of marriage fraud surrounding the 2012 immigration policy amendments (Citizenship and Immigration Canada, 2012), there is little doubt that these proliferations reach the media. 
Constable (2012) speaks to the creation of moral panic over 'threats' to sanctity of national borders. Watson and Riffe (2013) mention that these immigration threats, such as the one surrounding fraudulent marriage emphasized by the Canadian government (Citizenship and Immigration Canada, 2012), have far reaching effects. Generally, governmental objectives and media proliferations are mirrored (Walgrave, Soroka, \& Nuytemans, 2008). Media does shape public perception on topics like immigration (Soderlund, 2007; Watson and Riffe, 2013). Newspapers are especially influential in regards to swaying public opinion (Walgrave, Soroka, \& Nuytemans, 2008).

While there are a multitude of channels in which representations can be proliferated, for the purpose of my research and following the arguments of Walgrave, Soroka, \& Nuytemans, (2008), newspapers have been selected as the focus of analysis. Through an analysis of newspaper coverage of this topic, I hope to uncover some of the ways that "mail order brides" are being represented, to learn more about how the general public is learning about this topic. Generally media, inclusive of newspaper reports, are internalized by the public as truthful; the general public, for the most part, accepts what is brought to their attention via media and utilises this information to construct or reinforce their attitudes and realities (Soderlund, 2007; Surette, 2014; Watson and Riffe, 2013). The way a "mail order bride" is portrayed within a newspaper can either assist or hinder her worthiness of protection. Therefore, my proposed research question is: How do newspapers in Canada portray "mail order brides"? What messages are Canadians getting about these women (and the men they marry) through the newspapers that they read? 


\section{Author's Social Location}

It is important to take into account my social location as a study on the topic of "mail order brides" is conducted. I have a traditional Italian upbringing; I use the word traditional to indicate the expected gender roles of women and men in a patriarchal system. In my household, as well as in the households of many of my Italian friends, women are expected to cook, clean and maintain the family while the male of the household is responsible for working outside the home. These gendered roles are far more deep rooted than simple tasks to help the family function. Through my lived experiences I have found that these imposed gender roles are a tool to control and oppress women.

I have been reprimanded on numerous occasions by extended family for questioning my role. At family dinners, the men and boys were not subjected to the large table clearing process. Being young, I expected that my brother and I should be treated equally and allowed to go play; however, my identity as a girl led to the expectation that I should stay and help clean while my brother had freedom from chores. I felt wholly consumed by this inequality with no recourse; the women around me reinforced that this was the expected way of life.

The internal turmoil I felt growing up due to my restrictions because I am a woman pushed me to pursue any university course related to women and their experiences. I had the privilege of taking a first year women's studies course taught by Dr. Sharon Sbrocchi, at the University of Ontario Institute of Technology; this sparked my desire to study any and all issues relative to women. It was also through Dr. Sbrocchi that I learned to better, critically understand my lived experiences as they would give me the passion needed to pursue research. Therefore, my lived experience of gender inequality at home has been the catalyst for my interest in structural level gender inequalities. The gender inequalities imbedded in the "mail order bride" 
immigration policies within Canada have come to my attention because of my epistemological beliefs. The experiences that have made me a feminist prompts me to explore "mail order brides" in newsprint media.

\section{Theoretical Framework}

I believe the experiences of "mail order brides" are best understood using a feminist framework. Through the application of a feminist lens, there is focus on the differing experiences of men versus women because of their gender. While gender and gender roles vary culturally, there continues to be universality of gender hierarchies despite the improvements of women's position in some contexts. Even within individual socioeconomic classes women continue to be oppressed at the hands of men (Offen, 1988). Belleau (2003A) speaks to universal gender hierarchies in connection with "mail order brides". She provides the example that in many parts

of the world, women are not the primary inheritors of wealth or property. Ergo, with the majority of the resources and assets being given to the men, women find themselves in destitute positions and may turn to the option of becoming a "mail order bride" (Belleau, 2003A).

Gender roles can be defined as the way an individual is expected to behave and which tasks they are expected to take-on within and outside the family setting. Feminists would have something to say about social policies that assist men in seeking traditional women. It has been argued by some that independent attitudes among women in the west are seen as undesirable by some western men (Lloyd, 2000; Miteva, 2006; Narayan, 1995). Thus, some western men, due to their patriarchal/traditional views, may seek women who they perceive to be more dependent, especially economically. These men may then seek brides abroad who they believe may embrace more rigid and traditional gender roles. 
As mentioned earlier, patriarchy is the infusion of male dominance in societal structures which specifically exists to subordinate and negatively affect women (Offen, 1988). Through hegemonic masculinity, or male supremacy, there is discussion not only about gender constructs and gender roles, but also structural processes that favour men (Connell \& Messerschmidt, 2005). Through male hegemony, connections can be made about the "mail order bride" industry; for example, the existence of immigration policies that make women dependent on their male counterparts may heighten the possibility of abuse. Not only does patriarchy allow for the construction of women's expected roles in society, but it also encompasses the societal workings that are undertaken and in place in order to oppress women.

While there are numerous feminist lenses, I plan to utilise a combination of radical feminism and socialist feminism. Radical feminism focuses on the structural oppression of women, highlighting that revolutionary change is required. It is not enough to revise small policies and social relations; instead there needs to be an overhaul of the structural status quo and an infusion of norms that promote equality between men and women (Chambers, 2005). The above expression of radical feminism is in stark contrast to the societally accepted notion of what it means to be a radical feminist. The general stereotypes associated with radical feminists include the label of 'extremists that despise men'. Similarly it is assumed that women who selfidentify as radical feminists want to subordinate men. Comments on appearance, such as manly or women who choose not to shave, are also included in the stereotypes. These stereotypes overlook the main purpose of the theory, which is to end the commodification of women (Mackay, 2015). All of these negative references dissuade women from identifying as supporters of radical feminism. 
The radical feminist lens connects with the "mail order bride" phenomenon, as some argue that commodification of women is rampant (Belleau, 2003B; Chaudhuri et al., 2014; Grosh, 2011; Kusel, 2014). Especially in connection to human trafficking, women may be lied to and coerced into unfavourable lifestyles (Newsome, 2007). While the majority of radical feminists frame women as victims, some authors like Levy and Jakobsson (2013) state that radical feminist portrayals of human trafficking are not fully developed. While radical feminists wish to aid in the abolition of the sex industry due to its 'connection to patriarchy', it removes any acknowledgment of women's agency (Levy \& Jakobsson, 2013).

The conflation between human trafficking and the sex industry cannot be justified as human trafficking must always have an element of coercion and deceit as noted by the United Nations (Hussein, 2015). Thus, through the comparisons between "mail order brides" and human trafficking, the aim is to highlight the lack of agency through the process. Constable (2012) would disagree and posits that the regulation of the "mail order bride" industry is yet another patriarchal tool to control women's bodies. As well, it portrays these women as passive victims, as opposed to individuals who have ability to make informed decisions (Constable, 2006; Hodges, 2010). While I agree that some women may have agency, the aforementioned element of coercion and deceit that accompanies trafficking as mentioned by Hussein (2015) and Newsome (2007) removes the potential for complete agency. My intent is not to dissolve the distinction between human trafficking and sex work. While Bernstien (2010) states that many western feminists are removing the distinction between specifically sex trafficking and sex work, I do not intend to align my views with, as she remarks, support for a nuclear lifestyle and the condemnation of sex work. However, I do recognize the connection between the coercive element in human trafficking and that same potential coercion that "mail order brides" may face. 
Simply, I argue a "mail order bride" cannot have full agency when being trafficked, as coercion is a main element in trafficking.

Belleau (2003B) also notes that sexism in the husband's country of origin may propel the commodification of women; these women may be acquired as merchandise for the purpose of pleasing the man who is disgruntled by the selection of women in his home country (Belleau, 2003B). While Belleau (2003B) simplifies the "mail order bride" phenomenon to the purchase of an item by impulsive men, she attempts to bluntly highlight the inequality in the process. I would argue that Belleau (2003B) speaks from a radical feminist lens as she pushes for the acknowledgment of the control the husbands have over these women.

The inclusion of socialist feminism is important, because aside from the control of women's bodies and sexuality as proposed by radical feminists, one must acknowledge the connection patriarchy has to capitalism and culture. Male supremacy is existent around the world, but in different forms with varying degrees (Ehrenreich, 2005). The main focus of socialist feminism is the inclusion and intersection of class, which is not included in radical feminism (Holmstrom, 2003).As aforementioned, globalization and neoliberalism play a role in how women from different parts of the world experience patriarchy. As an example, some women from the global south are largely disadvantaged and the "mail order bride" industry preys their unfavourable position (Lloyd, 2000). Even in regards to property rights, as aforementioned, women are often not left any property nor assets, but instead the males of the family inherit everything (Belleau, 2003A). In some cases, becoming a "mail order bride" has been provided as another option to pursue economic opportunities in the global north in order to advance women's destitute positions (Belleau, 2003A; Belleau, 2003B; Grosh, 2011; Zare \& Mendoza, 2011). 
Globalization has affected everyone across the world in different ways and socialist feminists argue that it has disproportionally hindered women's status (Holmstrom, 2003). While I accept this argument, I would also go further to argue that women face the consequences of globalization differently depending on one's geographic location - whether that be the global south or global north. Thus, not only must we regard the situation "mail order brides" face as exploitation and control over their bodies, but also as a cultural and economic organization that negatively affects women across the globe, differently.

The work of Chaudhuri et al. (2014) discusses the concept of patriarchal bargaining, whereby women, specifically in South Asia, work within the constraints of patriarchy to improve their position. Offering a simplistic explanation, women will attempt to advance their unfavourable circumstances, by choosing options that are the lesser of the evils - even if that means accepting and/or reproducing patriarchy (Chaudhuri et al., 2014). Patriarchal bargaining then, does not advocate for revolutionary change like the premise of radical feminism. By offering small revision of contemporary issues, there is no solution to the problem of patriarchy. Dating back to the Roman Empire, men had control over women and property (Wardle, 2008); today we can still see the maintenance of this way of functioning. There is need to question the contemporary and work toward global normative change.

\section{Methodology}

\section{Approach \& Strategy}

An exploratory, qualitative approach was utilized to conduct this research. This approach was best because there is relatively little information or research about the international phenomenon of "mail order brides". From what I have found, only a handful of researchers, including Marie-Claire Belleau (2003A), have undertaken this topic in a Canadian context. 
Therefore, it was important to partake in exploratory qualitative research to begin collecting additional information on the topic of "mail order brides" in Canada. The hope was that by conducting qualitative research, it would allow for the creation of new concepts and approaches to understanding Canadian perceptions and the lived experiences of "mail order brides".

A qualitative content analysis of newspaper stories was the strategy utilized to gain information on "mail order brides" within Canada. The content analysis of newspaper reports gave insight to trends in reporting on "mail order brides". Similarly, it was important to keep in mind that any trends in reporting are being provided to the populous. Again, referencing Surette (2014), the media can be considered a channel of truth for those in society. Even those who skim briefly are infused with constructed notions that may hold bias. Ergo, it is important to analyze what is within the newspapers in order to understand what the general populous may accept on a topic that is minimally studied in Canada.

The primary use of content analysis has shifted focus from quantitative to qualitative, with qualitative being the contemporary focus (Hsieh \& Shannon, 2008). Qualitative content analysis is used to learn about a phenomenon or an event through the study of numerous kinds of samples, inclusive of print media (Elo \& Kyngas, 2007; Hsieh \& Shannon, 2008). Inferences can be utilized to gain not only the manifest content, but the latent content as well (Elo \& Kyngas, 2007; Hsieh \& Shannon, 2008). Through reading the text, the purpose is to uncover the "meaning, intentions, consequences and context" (Elo \& Kyngas, 2007, p. 109). Both Elo and Kyngas (2007) as well as Hsieh and Shannon (2008) address the contention with gathering latent, or inferred data. While subjective in a sense, I have divulged my social location above, as well as discussed my theoretical lens. Ergo, I am aware of my personal biases and have also informed the reader. 
Through this research, there was a use of inductive method. Since there has been minimal Canadian research conducted on the topic of "mail order brides", I felt it was important to allow categories and findings to emerge from the data, as opposed to pre-constructing categories and searching for data that correlates (Elo \& Kyngas, 2007; Hsieh \& Shannon, 2008). However, due to the copious amount of reading I have done on the topic, I was not without preconceived notions about what the data would bring. Thus I had some pre-constructed categories to begin my data analysis (Elo \& Kyngas, 2007; Hsieh \& Shannon, 2008). This is also considered directed content analysis as there has been prior research conducted on "mail order brides", but I feel it was incomplete in the Canadian context (Hsieh \& Shannon, 2008). Ergo, I used a combination of an inductive and deductive approach to complete this content analysis.

\section{Operational Definitions}

As noted above, "mail order bride" is the term that I used to refer to women from outside of Canada that market themselves via online forums for the purpose of attaining a Canadian husband. The term "mail order bride" is not only a label, but the process of selection and emigration from one's country of origin into Canada. In relation to IMBs, the use or lack thereof does not hold any weight on the definition. To focus on IMB categorization as part of a definition would have limited the scope of the research and left out an important part of the "mail order bride" population. When searching for newspaper articles, I used the following terms to refer to and identify newspaper stories on this topic: mail order bride, mail order brides, mailorder bride, mail-order brides, mail order marriage, mail order marriages, internet bride, internet brides, E-bride, E-brides, foreign bride, foreign brides, marriage migration, international marriage broker, international marriage brokers, marriage broker, marriage brokers, foreign wife, 
foreign wives, bride migration, international bride, international brides, international marriage and international marriages.

\section{Sample Frame}

The sample frame for this research was newspaper stories that contain the terms mentioned above. While both online newspapers and tangible print copies were available, there was a sole focus on those that are available as an electronic copy but have previously been produced via print. The reason for this selection is that even with the numerous forms of technology, like cellular devices and computers, society still prefers to read print news (Vividata, 2015). Vividata (2015) is a data collection body that specifically studies newspaper and magazine readership as to provide yearly statistics to companies or individuals who wish to advertise within these media forms. Readership statistics were also of interest as a researcher, since there is focus on print newspaper influence on society; it was imperative that the sample selection has a wide readership in order to promote the validity of the study.

In combination with the focus on print newspapers, it was essential that newspapers with a wide reach of audience were selected. Certain newspapers are strictly local and serve their individual communities; large scale newspapers are necessary for this study. The Toronto Star, the Globe and Mail, the National Post, the Toronto Sun, the Ottawa Citizen, the Vancouver Sun and the Montreal Gazette all have wide readership either nationally or within their respective provinces. It is important to note that while print newspaper viewing is low from the National Post, the online duplicate of the print has immense viewing (Vividata, 2015). Therefore, while print newspapers were the focus, they are often translated into digital copies, providing even greater societal reach. 
The reason for choosing these specific newspapers varies. In terms of the National Post and the Globe and Mail, their selection was essential as they represent a national level news source (Vividata, 2015). While the Toronto Star has wide readership, which happens to be the reason for its selection (Vividata, 2015), the Toronto Sun was chosen due to its conservative political stance. There is reference of the founders and columnists being conservative, thus one can accept that these political biases may infuse the media pieces within the newspaper (Worthington, 2013).

The reason for choosing the Montreal Gazette was rooted in immigration law and policy. The primary reason for its choice is that since 1991, Quebec was given control over immigration into the province; other provinces in Canada are not afforded the same abilities (Scott, 1995). Second, while there are many newspapers within Quebec, the Montreal Gazette was chosen due to the wide readership within Quebec (Vividata, 2015). Finally, the Vancouver Sun was selected because it is one of the top three immigrant hubs in Canada along with Toronto and Montreal (Good, 2009); thus, this was an important geographical region to include in the sampling frame. The Vancouver Sun was specifically chosen also because it is the paper with the highest readership in that geographical location (Vividata, 2015).

For the retrieval of these newspaper articles, I used the online database through Ryerson's Library. Canadian Newsstream offers an online reservoir of print newspaper articles. The reason for selecting this online database is that it is an easy and efficient way to search for articles from anywhere, as long as you have internet connection. This database only covers Canadian newspapers, thus it links to the Canadian focus of my research question. The use of this online source allowed both PDFs as well as print copies to be made of the articles for analysis. 


\section{Criteria for Selection}

The criteria for selection of the news articles within the aforementioned newspapers was reflective of certain time periods. There are two large policy changes that have occurred within the last fifteen years that are integral to sentiment regarding "mail order brides". The first time period that was analyzed is from January $1^{\text {st }} 2000$ to December $31^{\text {st }} 2004$. The reason for selecting this time period is because I was interested in analyzing the media portrayals of "mail order brides" surrounding the reduction in sponsorship period from ten to three years in 2002 (Belleau, 2003A; Belleau, 2003B).

In contrast, there was a policy amendment that hindered the push toward independence and safety of "mail order brides" within Canada. As aforementioned, as of 2012, a "mail order bride" must now live with her sponsor for two years if they have been together for two years or less prior to her arrival in Canada (Citizenship and Immigration Canada, 2014). Therefore, the second time period for comparison was January $1^{\text {st }} 2010$ to December $31^{\text {st }} 2014$. The goal of analyzing these two time periods was to find differences in portrayals of "mail order brides" in print newspaper stories surrounding the advancement of protections for the brides, versus the hindrance of protection.

In order to give an explanation for including both the two years preceding and following the year of policy amendment, it is important to consult scholarly research on qualitative content analysis. There are minimal newspaper stories on the topic of "mail order brides" for the policy change years of 2002 and 2012. Therefore, there was a need to broaden the search timeframe. The inclusion of one year preceding and following did not allow for many stories in 2012, thus two years was selected. The necessity for numerous stories is reflected within the trends of previous scholarly works. Miller et al. (2014) completed a content analysis with a total of 339 
articles. Similarly, Fagan et al. (2014) utilised 100 newspaper stories within their study. While these studies are not on the topic of "mail order brides", it portrays the trend of including numerous articles in one's study.

The accumulation of more stories would have been beneficial to this study, however there were constraints that are rooted in politics. As an example, increasing the preceding and following years surrounding the policy to three years would create unnecessary complexities. In October 2015, a majority Liberal government was elected in place of Conservative leadership. Thus to extend the time period surrounding 2012 to 2015 would make for difficulties when judging political influence in the analysis. I also wanted to maintain the same length of time surrounding each policy amendment in order to keep comparisons fair. Thus, while there was slight limitation in gathering numerous articles, it was the lesser evil when considering the complexities of encroaching on the election of a different political party within 2015.

Search terms are also important selection criteria. As noted above, there are multiple terms used to denote "mail order brides" that were utilised as relevant search words for article selection. Preliminary research on news articles led to the unveiling of multiple phrases that are intrinsic to this study. Without the use of multiple key phrases, there would have been a large section of the researchable newsprint pool that would have been overlooked. Thus, it was essential to deduct how certain populations are referenced before conducting a study.

In terms of specific articles, the criteria for selection was the mention of "mail order brides" in any non-fictional way. There has been mention through the media of theatrical productions referencing "mail order brides", as well as other fictional accounts. However, for the purpose of this research the analysis and collection of non-fictional accounts and portrayals of "mail order brides" was needed. I utilized the population of stories available in the aforementioned time 
periods to complete a comparative analysis, since there were enough stories to perform sampling. Consalvo (1998) conducted a content analysis of newspapers focusing on the murder of a "mail order bride" and she utilized the population of relevant stories. Fagan et al. (2014) also collected the population of stories relevant to their topic of study. Thus, using the population of relevant stories is common when sampling is not possible due to a low frequency of newspaper reporting on specific topics. Since there were no human participants in this study, ethics review was not necessary.

\section{Data Collection Procedures}

There is a multitude of data that can be collected while reviewing print newspaper articles. The primary information collected was the page number and section in which the newspaper stories appeared. Placement within the newspaper signifies an article's importance (Miller et al., 2014). As an example, the most important articles can be found on the front page of one of the sections, with the front page of the first section signifying utmost importance. As for the length, the amount of words and space afforded to an article correlates with its importance. As a whole, articles that are longer and nearer to the front of sections hold more importance than those that are short in length and nearer to the end of sections.

Another point of interest in regards to data, is the sex of the journalist who is reporting on "mail order brides". It was important to collect this information so that I could analyze whether or not the sex of the journalist promotes more positive or negative discussions of "mail order brides". There are circulating beliefs that females are more sympathetic than males when coming into contact with other females who are experiencing difficulties. However, this assumption was disproven in the refugee hearing sector. In a study conducted by Rehaag (2011), it was expected that female adjudicators would be more sympathetic toward female claimants; however, the 
results indicated otherwise (Rehaag, 2011). Thus, it would be similarly incorrect to make assumptions based on a journalist's sex in relation to the portrayal of "mail order brides" through newsprint.

Citing sources within newspaper articles helps to prove the argument that the journalist may be trying to make. However it was important to take note of who the journalists were citing (Miller et al., 2014). For example, they may cite reliable sources such as immigration officials; in contrast they may provide quotes from public opinion. Husbands or "mail order brides" may also be credited within stories. Depending on what source a journalist uses, there may be bias imbedded and/or unreliable feedback that can skew readers' perceptions. Both the source as well as how it is used can either positively or negatively impact the protections provided to "mail order brides".

Both the tone of the story as well as who the story is critical of was important data to collect. The tone of the article can take many forms inclusive of anger, worry, fear, sympathy, activism, prohibition and other dualisms. As Kuykendall (2012) explains, tone incorporates neutrality, positivity or negativity toward a certain subject. Perhaps different tones are attributed to the "mail order bride" versus the husband. The article may also be critical of none, one or both of these parties. It was important to collect data on both tone and the critical lens placed on certain subjects, since these views are being proposed to the general populous.

Data related to discussions about specific countries and factors that prompt the "mail order bride" industry were also in need of collection. In connection with the discussions of countries, it was of interest to see if the newspaper articles focus on the country of origin of the "mail order bride". Alternatively, they may focus on the receiving countries of "mail order brides". To connect to scholarly literature, linked to the discussion of countries are the factors 
that prompt the "mail order bride" phenomenon. These include but are not exclusive to monetary inequality or broader structures like neoliberalism (Belleau, 2003A; Belleau, 2003B; Grosh, 2011; Zare \& Mendoza, 2011).

Another example of data that was collected is the language surrounding the "mail order bride" phenomenon. As an example, was crisis language utilised to denote the immigration of "mail order brides"? This section can be closely connected to the announced factors that prompt the phenomenon - if fraudulent perceptions are proliferated, that could be linked to both crises and securitization language. Alternatively, language advocating for policy amendment and more protective frameworks for "mail order brides" can be considered positive portrayals. As aforementioned in the review of existing literature, Zare and Mendoza (2011) found that the dichotomy of victim and deceitful were common among the fictional portrayals of "mail order brides". Thus, through this study on newsprint, it was interesting to analyze if these accounts within fictional portrayals translate to non-fictional newspaper articles.

\section{Recording and Organizing Data}

To record the aforementioned data, I used a laptop (with a passcode); the data saved on the laptop was also uploaded onto a storage drive in case of technological malfunctions. As well, since I am partial to written analyses, printed copies of the newspaper articles with written notes were kept in a folder not accessible to anyone but myself. The multiple forms of data collection ensured that there was a backup so that the data was not lost. The passcode used for the digital copies and private folder used for the printed copies allowed the data collected to be kept secure.

My plan for organizing the data was adopting a similar format to Dr. Phillip Shon's RCOS method of organizing literature for literature reviews. Two tables were utilised, one indicative of 2002 policy change and the other of 2012. Shon (2012) outlines certain word 
indicators to attribute to journal articles, as well as final tables in which to concisely input all the analyzed articles. As an example of indicators, for a depiction of a fraudulent "mail order bride" one could input square brackets around the particular sentence and make a note in the right hand margin stating 'fraud depiction'. A list of indicators were created prior to beginning the research, however the list was not static. It was imperative that alterations were allowed through the process of qualitative research; new and emergent findings that have not been previously considered are also integral to incorporate as the research progresses (Elo \& Kyngas, 2007; Hsieh \& Shannon, 2008).

The aforementioned tables consist of rows and columns to input findings. The columns allowed a compilation of articles that have been assessed. Alternatively, the rows signify the type of data being collected that were mentioned in the previous section - sex of the journalist, page and section of the article, date published, etc. This allowed a concise representation of the data collected through the use of keywords and square brackets via the printed copies of newspaper articles. Rather than flipping through the numerous articles to find patterns and trends, all the information was coded and organized in tables, making comparisons between time periods more simplistic; a short example is provided below.

\begin{tabular}{|l|l|l|l|l|}
\hline$\#$ & 1 & 2 & 3 & 4 \\
\hline Title & & & & \\
\hline Newspaper & & & & \\
\hline Sex of Author(s) & & & & \\
\hline
\end{tabular}

\section{Interpretations}

The way "mail order brides" are portrayed through Canadian newsprint will often exemplify what the populous internalizes. Comparing newspaper stories surrounding two different policy objectives will allow for a better understanding of media's role in promoting complacency. Once it is known how "mail order brides" are portrayed, there can either be a push 
for a more positive portrayal, or the maintenance favourable proliferations in order to advocate for safeguards for "mail order brides". I argue policy change is needed to better the conditions for "mail order brides" arrival in Canada.

\section{Contextualizing the Results}

The organization of the findings section follows the format of the literature review. I selected key terms/ideas that I felt relevant within the previous literature and utilized them as subheadings and points of focus when discussing the results of my content analysis. I begin by outlining the general findings for both time periods that emerged through my research. While the general findings section did not emerge in connection to previous literature, it is in place to give the reader an overview of the news stories, inclusive of political alignment. Next, I discuss 'Mention of Policy Flaws in Stories' as policy is central to this paper. Due to the change in policy, the different governmental objectives bring about 'The Presence and Subjects of Blame in News Coverage', thus blame was also integral to analyze. A discussion on 'The Use of "Fraud" and Who it is Directed Toward' follows, as it is also linked to policy; specifically in connection with the government's crackdown on marriage fraud surrounding 2012 (Citizenship and Immigration Canada, 2012). As a fifth subheading, an analysis of the 'Connections between “Mail Order Brides” and Human Trafficking' was essential because some conflate human trafficking with the "mail order bride" phenomenon (Constable, 2013; Newsome, 2007). 'Reporting on "Mail Order Brides" and/or Western Women as 'Traditional' 'is used as a subheading to analyze if the arguments proposed by Newsome (2007) and So (2006), that men seek more traditional women, hold validity through newspaper portrayals of "mail order brides". Next, 'Discussion of Domestic Violence/Abuse in the Stories' was imperative to note due to the large amount of scholarly literature that states it is rampant within the "mail order bride" 
phenomenon (Grosh, 2011; Kusel, 2014). The different arguments proposed by Merriman (2012) versus Grosh (2011) and Kusel (2014) prompted the seventh subheading, 'The Narrative of "Choice” in Newspaper Coverage', which analyzes if "mail order brides" have a 'choice' in marrying foreign men. The final subheading focuses on the analysis of the 'References to Social/Structural Inequalities' within the news coverage, which is integral to the feminist lens of this paper.

\section{Results/Findings}

\section{General Findings}

There were 22 news stories collected for the time period surrounding the 2002 policy amendment; six stories came from the National Post, three from the Globe and Mail, two from the Ottawa Citizen, three from the Toronto Star, four from the Vancouver Sun and four from the Montreal Gazette. Despite the inclusion of the Toronto Sun in the search for relevant stories, there were no results from this newspaper. The collection of stories equated to 10 national and 12 local newspaper sources. As for political alignment, 12 of the news stories came from conservative newspapers, three derived from liberal newspapers and the remainder, seven, came from centre aligned newspapers. More than half, 12 of the 22 news stories, focused on Canada as a country of import. While not all the stories have a Canadian focus, newspaper reports that focus on other countries may still shape public opinion.

Surrounding the 2012 policy change, there were a total of 10 news stories collected. Two stories came from the National Post, one from the Ottawa Citizen, two from the Toronto Star, four from the Vancouver Sun and one from the Montreal Gazette. Similar to the 2002 time period, no news stories derived from the Toronto Sun; however, this time period also gained no news stories from the Globe and Mail. Eight of the 10 news stories are local, while two are 
national. Seven of the stories are aligned conservatively, two are liberal and one is considered centre. Like the 2002 time frame, there is a high representation of conservative news stories, arguably because the majority of the newspapers selected are conservative. Also similar to the period of 2002, more than half of the stories (six of 10) surrounding 2012 focused on Canada. Again, despite there being some focus on a different country, Canadian public opinion may still be shaped through portrayals in these news stories.

\section{Mention of Policy Flaws in Stories}

Regarding policy surrounding 2002, five of the 22 news stories mentioned that there was a flaw in current policy that needed to be addressed. Of the news stories that made mention of a flaw in policy, three are centre aligned papers, while the other two are conservative. One of the news stories did not go further to mention what aspect of policy was flawed and two others commented on a policy aspect that was not accounted for in the coding manual. The remaining two news stories focused on policy flaws that revolved around both husband screening and IMB policies. Reflecting on pre-existing literature, the United States, unlike Canada, has IMBRA to provide screening of potential husbands (Constable, 2012; Newsome, 2007; United Nations, 2010). Both stories focused on the United States, one preceding IMBRA and one after IMBRA was enacted. The news story by Bramham (2002) from the Vancouver Sun points to the case of a "mail order bride" who had unknowingly married a serial killer after he had completed his sentence. As she later became one of his victims, there stands argument for the implementation of "mail order bride" protections. The news story states that the companies facilitating the "mail order bride” phenomenon “... aren’t bonded, and if something goes wrong, they carry no liability. And things do go wrong..." (Bramham, 2002, p. B3). Thus, the news story by Bramham (2002) emphasizes the need for the implementation of IMBRA. Parfitt (2003) from the 
Montreal Gazette claims that the implementation of IMBRA was catalyzed by the case of Anastasia King, a "mail order bride" who was murdered by her husband. As well, IMBRA “...is being seen in the U.S. as the most serious effort yet to impose federal controls over a loosely regulated Internet-based industry" (Parfitt, 2003, p. A9).

Mention of policy flaws surrounding 2012 can be noted in two of the 10 news stories. One of the news stories by Todd (2010) from the Vancouver Sun notes that the sponsorship period as well as "mail order bride" screening is flawed. The much advocated lengthening of sponsorship emphasizes that a "... waiting period would help expose phoney unions" (Todd, 2010, p. A4). The other news story by Humphreys (2011) from the National Post states that there is a flaw in sponsorship process only. A Toronto immigration lawyer notes that, "The court is sending an equivocal, clear and loud message that it will not allow the taxpayers to shoulder the burden of those who have acted carelessly or obliviously to the responsibility of fulfilling the terms of a sponsorship for a relative" (Humphreys, 2011, p. A11). This comment is in reference to making sure sponsors pay back the government for what social assistance their sponsored relative, or "mail order bride", utilizes during the sponsorship period (Humphreys, 2011). The 2012 news media analysis on policy flaws portrays that protections for "mail order brides" are not in the forefront.

While both time periods appear to mention policy in similar proportion, there is contrast in the types of policy flaws that are noted. Surrounding 2002, the need to oversee IMBs and screening of husbands was at the forefront. The media portrayals from 2000-2004 correlate with the governmental objectives surrounding that time period; the protection of "mail order brides" from deceptive relationships and the reduction of "mail order bride" dependence was the main focus (Belleau, 2003A; Belleau, 2003B; Immigration and Refugee Protection Regulations, 
2002). In the 2010-2014 time period, both articles are situated prior to the 2012 policy change that lengthened the sponsorship period for "mail order brides". Thus, the news stories may be reflective of the policy objectives of their time, which does not include an interest in reducing "mail order bride" dependence, but instead seeks to prevent abuse of Canada's immigration system (Citizenship and Immigration Canada, 2012).

\section{The Presence and Subjects of Blame in News Coverage}

Through my research I gathered information on the broad notion of blame; I was interested in whether individuals, the state, or larger global structures are to blame. From the 2000 - 2004 time period, two news stories blamed a combination of individuals and the state, two stories blamed the state and 10 stories stated that individuals are blameworthy. Thus, a total of twelve news stories make mention of individual blaming. To further analyze blame, I gathered information on which individuals were blamed specifically; one news story blamed "mail order brides", one news story blamed a combination of "mail order brides" and the husband, two blamed a combination of husband and IMBs, one blamed the husband and four blamed IMBs.

In the news story by Turley-Ewart (2004) from the National Post, there is clear disdain toward the Chinese women who are considered dependent; these "mail order brides" are being blamed for the 'takeover' of Taiwan. Within the news story it is stated that “...Taiwan's official independence is being jeopardized by a more surreptitious means than brute force: Chinese women marrying Taiwanese men" (Turley-Ewart, 2004, p. RB3). Despite the one negative news article, it is noteworthy that the others shift blame to other sources rather than the "mail order brides". Chipman (2001), also from the National Post, had individual blame for the husband as well as the "mail order bride". In this story the husband was being investigated for murder but the husband's opinion was included, which shone light on the potential marriage sham his "mail 
order bride" was scheming. However, a police officer who was part of the murder investigation noted that the husband "...is being looked at, and we are still feverishly investigating a lot of different angles" (Chipman, 2001, p. A14). The overall contention with these findings is the lack of acknowledgment for macro issues faced by "mail order brides", instead blame remains on the micro level; this pattern repeats itself throughout the remainder of the findings.

Surrounding 2012, through the analysis of the broad notion of blame, seven of 10 news stories blame individuals, while two of the 10 stories blame both individuals and the state. Four of the news stories blamed "mail order brides" and one news stories blamed the husband. The only news story to place blame on the husband was by Aulakh (2014) from the Toronto Star. The focus of this news story is United Arab Emirates, Saudi Arabia, Jordan, Kuwait and Oman. Aulakh (2014) speaks of the "mail order brides" as victims of abhorred men, which may not appear to align with Canadian policy goals, but that is specifically because this news story does not have a Canadian focus. There are a group of women who attempt to expose these men that seek young "mail order brides" by setting up "sting operations" so that their reputations will be ruined. One of the women, Nishat, states, "He should be so scared that he shouldn't do it" (Aulakh, 2014, p. WD4).

The fact that husbands are blamed in the news story by Aulakh (2014) and that there are different non-western countries of focus points to an issue discussed in the literature. Lloyd (2000) and So (2006) discuss the glorification of the global north and demonization of the global south. So (2006) explains that upon discussion of countries in the global south, "mail order brides" require saving from both the "third world" as well as the men from these geographic locations. The sole focus on demonizing men from the global south, removes Canada from any fault, as if abuses do not occur within these northern jurisdictions (Lloyd, 2000). Thus, while the 
husband blaming mentioned in the liberal story by Aulakh (2014) does not appear to correlate with Canadian governmental objectives, the finding is congruent with previous literature that mentions Canada's role in demonizing the global south.

The overall trends in blame are dissimilar for the two time periods analyzed. While for 2002, blame was placed on husbands and IMBs, "mail order brides" are the biggest focal point of blame surrounding 2012. The focus of blame correlated with the policy goals of each respective time period. Belleau (2003A), Belleau (2003B) and Immigration and Refugee Protection Regulations (2002) maintain that policy surrounding 2002 was interested in protecting "mail order brides"; Citizenship and Immigration Canada (2012) states that surrounding 2012, potential sponsors and the immigration system need protection against those who seek marriages of convenience. The aforementioned outlier in the 2012 time period was discussed and rationalized.

Another finding that can be linked to scholarly literature is the lack of acknowledgement for more structural issues that negatively affect "mail order brides". Both time periods are heavily focused on individual blame with minimal mention of state blame. I added 'global structures' as an option in my coding table, however not one news story touched on larger, deep rooted issues. The lack of discussion of structural issues correlates with the arguments of Grosh (2011) and Kusel (2014) who continuously blame IMBs for exploiting "mail order brides" (like the rhetoric mentioned in the 2002 time period news stories). As Offen (1988) mentions, the subordination and exploitation of women cannot simply be associated with individual blame, but it is rooted more deeply in the structures of society.

\section{The Use of "Fraud" and Who it is Directed Toward}

Discussion of fraud and/or deception surfaced in over half of the stories surrounding 2002,13 out of 22 . Since noting the general mention of fraud and/or deception does not provide 
enough insight, information was also gathered on who was considered fraudulent and/or deceptive. Two of the 13 stories commented that the husband was fraudulent and/or deceptive and four noted that both husbands and IMBs were fraudulent and/or deceptive. Three of the 13 news stories mentioned that both "mail order brides" and husbands were fraudulent and/or deceptive. An article from the Toronto Star, McCabe-Lokos (2003), elaborates that the husband and the "mail order bride" are both willing to gain fake documentation through paying a consultant to avoid the long wait times for legal entry into Canada. However, the journalist focuses on the husband and states that one may “...opt for the Cadillac service: a mail-order bride complete with all the necessary papers and a flight to your chosen country for $\$ 25,000$ " (McCabe-Lokos, 2003, p. A3). In two other news stories, Schmidt (2003A) from the Vancouver Sun and Schmidt (2003B) from the Ottawa Citizen, there is discussion of husbands falsifying information when wooing "mail order brides" as well as "mail order brides" appearing more traditional in pictures in stark contrast to their progressive social position. When pictures were exchanged, "...men were younger and dressed in clothes they could not afford..." (Schmidt, 2003A, p. A8; Schmidt, 2003B, p. A3). Similarly, “...women chose flattering pictures that did not show their height or frizzy hair..." (Schmidt, 2003A, p. A8; Schmidt, 2003B, p. A3).

An interesting finding surrounding the 2002 policy change for "mail order brides" is that four of the 13 stories considered "mail order brides" fraudulent and/or deceptive. These stories all derived from conservative aligned newspapers. As well, it is important to note that none of these stories surfaced in 2002 specifically, but instead within the years surrounding the year of policy change; one story was from 2001, two from 2003 and one from 2004. Heinrich-Gray (2003A) in the Vancouver Sun and Heinrich-Gray (2003B) in the Ottawa Citizen question the intentions of "mail order brides" by inferring potential dishonesty. The journalist asks, "Who are 
these women? Why Are they hunting for men outside their native country?" (Heinrich-Gray, 2003A, p. A18; Heinrich-Gray, 2003B, p. C8). As well, the journalist adds, “...how do the men interested in meeting them, protect themselves from the people whose intentions are less than honest?" (Heinrich-Gray, 2003A, p. A18; Heinrich-Gray, 2003B, p. C8). While the remainder of the story sets a positive tone, the initial interrogative questions create skeptical reading and limitless disbelief in regards to these women marrying for love.

The news story by Chipman (2001) in the National Post focuses on the murder of a "mail order bride" in Washington and makes note of the husband allegedly being tricked into a fraudulent marriage by his "mail order bride". The husband states that "his wife had lured him into a sham marriage to circumvent immigration laws" (Chipman, 2001, p. A14). The final news story, also from the National Post, which focuses on a "mail order bride" outside of Canada, mentions that Chinese brides coming into Taiwan are treated as suspect and the lengthy wait times to gain citizenship are reflective of these suspicions (Turley-Ewart, 2004). As an example the journalists notes that, "Legislation prevents foreign spouses from obtaining full Taiwanese citizenship for nine years" (Turley-Ewart, 2004, p. RB3).

Fraud was discussed in four of the 10 news stories surrounding 2012. In all four of the news stories that discussed fraud, "mail order brides" were considered to be deceptive/fraudulent. Todd (2010) and Todd (2012), both from the Vancouver Sun, as well as Humphreys (2011) from the National Post and Keung (2013) from the Toronto Star, all make mention of marriages of convenience, or marriage fraud. They elaborate that women who are seeking to come to Canada and marry Canadian men should be better screened for potential fraud. As an example, an immigration lawyer notes, “...the recent rash of sponsors who have been duped by runaway spouses...should encourage people to think long and hard before they 
sponsor a relative... (Humphreys, 2011, p. A11). Another immigration lawyer from Vancouver that also worked for the Immigration Appeal Division states, "Marriages of convenience are a highly lucrative from of people smuggling...It's a big industry" (Todd, 2010, p. A4). However, it is worthy to note that of the six news stories that do not focus on fraud, only two of those stories focus on Canada as an import country. Therefore, the trend surrounding 2012 appears to point to fraudulent "mail order brides" being heavily discussed in the Canadian context.

Comparing the discussion of fraudulence/deception between both time periods does not bring similar proportional values. While only four of the 22 news stories from the 2002 time period considered "mail order brides" as fraudulent/deceptive, almost half, four of 10 news stories, surrounding 2012 found "mail order brides" to be fraudulent/deceptive. This may be indicative of the context behind both time periods. Surrounding 2002 there was a liberal government and protections were added into policy for "mail order brides". In contrast, 2012 brought conservative governance as well as a policy amendment that was a detriment to "mail order brides".

Referring back to scholarly literature, in 2012 the Canadian government instituted a policy change that specifically aimed to target marriage fraud and marriages of convenience (Citizenship and Immigration Canada, 2012). Like the fictional portrayals of "mail order brides" discussed by Zare and Mendoza (2011), through the news stories the dichotomy of victim and the deceptive is also portrayed. While in 2002, the victims were more often the "mail order brides", the depicted victims surrounding 2012 are husbands and the immigration system. As Grosh (2011) and Merriman (2012) note, "mail order brides" are frequently the subjects of disbelief and skepticism. The results from my analysis of news stories strengthens the aforementioned authors' arguments. 


\section{Connections between "Mail Order Brides" and Human Trafficking}

Almost half of the newspaper stories surrounding 2002 comment on human trafficking. Nine of 22 stories make mention of human trafficking, with seven of the nine explaining that trafficking is a catalyst for an increase in "mail order brides". The other two stories that mention trafficking infer that the "mail order bride" phenomenon actually causes human trafficking. Both stories that mentioned the "mail order bride" phenomenon as a cause of trafficking are written by the same journalist for different newspapers. Cody (2004A) from the Vancouver Sun and Cody (2004B) from the Montreal Gazette both speak to the lack of effective matchmaking in the "mail order bride" industry, which leads to marriage dissolution and a turn for the worst into human trafficking. As an example, a professor from National Chengchi University pinpoints that, "A lot of the brides are brides in name only... They can't be tracked down... Nobody knows where they are” (Cody, 2004A, p. A17; Cody, 2004B, p. D4).

Surrounding 2012, only two of the 10 news stories made mention of human trafficking. One of the two specifically mentions that human trafficking is the catalyst of the "mail order bride" industry. Aulakh (2014) from the Toronto Star explains that there are numerous individuals looking to partake in sexual activity with young girls, thus there is an offer of a monetary sum to families. Since these women come from impoverished families, the money offered is not refused. Often the arrangement is that the husband will take the girl as a "mail order bride", but at the same time these girls become victims of sex trafficking. A lawyer comments that "[n] eighbours would talk of girls disappearing overnight... or teachers would realize that a girl was gone when she didn't show up at school for a few days..." (Aulakh, 2014, p. WD4). As well, an activist who works for the Shaheen Women's Resource and Welfare Association notes that, " The parents will usually tell the girl that there is no money, not even to 
feed her siblings and if she marries (the older man), she will be the saviour of the family" (Aulakh, 2014, p. WD4). Overall the main focus of Aulakh (2014) from the Toronto Star is that "mail order brides" vulnerabilities are preyed on in order to push them into human trafficking. The waning conversation of human trafficking related to the "mail order bride" industry is not backed by scholarly literature. While Lloyd (2000) comments on the connections between the "mail order bride" industry and human trafficking, newer authors have surfaced. For example both Constable (2012) and Newsome (2007) make mention that it is generally western men who seek women from other countries as "mail order brides". Power imbalances surface because generally the men, who often have more monetary assets, will pay for all the immigration related fees (Constable, 2012; Newsome, 2007). While a rise in analysis of "mail order brides" as trafficking victims is evident in the scholarly literature, the same is not reflected through news stories. Again, noting the governmental shift in focus to combatting marriage fraud (Citizenship and Immigration Canada, 2012), it is no wonder that the dangers "mail order brides" face are not brought to the forefront.

Connecting to both radical and socialist feminism, surrounding the policy changes the mention of trafficking in "mail order brides" is associated with both control over women's bodies and economics. Within these news stories, it was put at the forefront that these disadvantaged women were becoming trafficking victims. While there was no connection to patriarchy, mention of poverty may point to the vulnerable state these women are in, which may make them prime targets for exploitation. It can be argued that the unmentioned presence of patriarchy led to destitute conditions for these women who face human trafficking, which correlates well with the economic viewpoint of socialist feminists (Holmstrom, 2003). Also, the discussion on sex trafficking within the news stories pinpoints the blatant exploitation of 
women's body and sexuality and this correlates with the main focus of radical feminism

(Ehrenreich, 2005).

\section{Reporting on "Mail Order Brides" and/or Western Women as 'Traditional'}

The work of Belleau (2003B) sparked my interest in the depiction of "mail order brides" linked to traditional relationships. Through her work, she explained how men who search for "mail order brides" do so because they are seeking more traditional relationships. These findings were reinforced through my own research; nine of the 22 news stories gathered from the time period surrounding 2002 noted that "mail order brides" are sought because they are perceived as traditional. Five stories went further and claimed that western women are less traditional which leads men to seek a "mail order bride". The comments of western women being less traditional all come from either a husband or from companies that promote the "mail order bride" phenomenon. As an example, some companies that advertise Russian brides comment that American women “...have less "traditional” values and high material expectations (HeinrichGray, 2003A, p. A18; Heinrich-gray, 2003B, p. C8).

The news stories from numerous newspapers, like Heinrich-Gray (2003A), HeinrichGray (2003B), Bramham (2002) and Bell (2000A), report on the opinions that companies that advertise "mail order brides" have regarding western women. By far the most unsettling example is from the story Bell (2000A) who quotes the information circulated by a "mail order bride" advertising company; "North American women are brought up to be greedy, selfish, manipulative and ungrateful ... They want a man only for his money and possessions" (Bell, 2000A, p. A10). In applying a radical and socialist feminist lens, the aforementioned husband's interest in women who are dependent as opposed to independent serves the purpose of reinforcing male dominance - both economically and physically. As well, a certain level of 
blame is shifted onto western women for seeking equality rather than subordination. As an example, a news story from the Montreal Gazette states that a man seeking a Russian bride feels that American women's “...need for independence leave[s] little if any room for serious committed marriage" (Ringle, 2000, p. D3). While the use of the word traditional in itself may not be taken negatively, the underlying meanings connected to its use are reflective of patriarchal values that seek to chastise women who do not accept subordination.

In contrast to the aforementioned findings, only one news story mentioned "mail order brides" as being traditional in the 2010-2014 time period. Again, in contrast to 2000-2004, this time period did not produce any news stories that denoted western women as less traditional. In the only news story that did mention "mail order brides" as traditional, the use of the word traditional was dissimilar to its use surrounding 2002. Manthorpe (2011) from the Vancouver Sun mentioned that many women in Asia are becoming educated and will not submit to a life of servitude, thus the reason "mail order brides" are being brought in from other countries. Women are torn between their own personal goals and cultural expectations; "Many women feel they face an either-or choice and opt for their careers" (Manthorpe, 2011, p. C3). There is no glorification of "mail order brides", but instead it gives reason for the "mail order bride" phenomenon in Taiwan and Japan.

It is important to refer back to previous literature to understand why the mention of "mail order brides" as traditional was inflated in 2002 and why it decreased significantly in 2012 . The focus in 2002 was the protection of "mail order brides" (Belleau, 2003A; Belleau, 2003B; Immigration and Refugee Protection Regulations, 2002). The word "traditional" is used to denote dependence and the inability to gain independence (Belleau, 2003B; Grosh, 2011; Narayan, 1995). Thus, it is possible that by overusing the word "traditional", it portrays that 
these "mail order brides" are in need of assistance and protection from those who will exploit their dependent positions.

While this tactic was helpful for a time period in which protections were at the forefront of the governmental agenda, the use of the word traditional has therefore waned in light of new governmental objectives. Following a shift in governmental objective, it seems that the media no longer must portray "mail order brides" as individuals who require assistance, but instead as those who are fraudulent and seek to deceive (Citizenship and Immigration Canada, 2012; Grosh, 2011; Merriman, 2012). Thus, from the perspective proposed by Citizenship and Immigration Canada (2012), "mail order brides" are not to be trusted; this sentiment is reflected in the news stories by not drawing attention to the disadvantaged positions of "mail order brides".

\section{Discussion of Domestic Violence/Abuse in the Stories}

From 2000-2004, 10 of the 22 news stories gathered make mention of domestic violence/abuse. Since I wanted to analyze this result without bias, I further questioned who this abuse or violence was directed toward. The options included a "mail order bride" by her

husband, the husband, as well as a "mail order bride" by her family. In this time period, 10 out of the 10 mentions of domestic violence/abuse were committed by the husband on the "mail order bride". Speaking to the immigration of Filipina women to Canada after they are sponsored by their husband, "...the typical mail-order wife is isolated; many are physically abused" (Alphonso, 2001, p. A3). As well, four of the 22 news stories made mention of intimate partner femicide (IPF) - the murder of a woman by her intimate partner. One particular news story notes that after the murder or disappearance of a "mail order bride", "In several of the cases, the 
husbands tried to collect on the life insurance they'd purchased for their brides" (Bramham, 2002, p. B3).

From the period of $2010-2014$, three of ten news stories make mention of domestic violence/abuse. The story by Aulakh (2014) from the Toronto Star mentioned that the domestic abuse toward the "mail order bride" was perpetrated by her husband. The news story by Curran (2010) from the Montreal Gazette noted that the abuse faced by the "mail order bride" was committed by her family. Families use physical violence and some “... women were killed after defying their family wishes by choosing their own husband or refusing a mate who had been selected for them" (Curran, 2010, p. A7). In both cases, it is important to note that the country of focus was not within the global north. Also, there was no mention of IPF within this timeframe; this is in stark contrast to the 2002 time period that had four news stories that mentioned the murder of "mail order brides" by their intimate partner.

The two time frames bring about two different, yet grievous trends that can be explained in connection to previous scholarly literature. Surrounding 2002, all mention of domestic violence/abuse came to the conclusion that "mail order brides" were targeted by their husbands. Despite the fact that only women were victims, the main focus, referring to the theme of blame, was to cast responsibility on individuals. While IMBs, husbands and other individuals may be to blame at face value (Grosh, 2011; Kusel, 2014), there needs to a deeper analysis of why these individuals and organizations believe it is ok to exploit and abuse women. Offen (1988) as well as Connell and Messerschmidt (2005) both speak to the fact that structures in society not only favour men, but also subordinate women. Continuously shifting blame onto different individuals is a temporary fix, but what is needed is upheaval of structures that promote inequality between men and women to promote revolutionary change and a solution (Chambers, 2005). 
The noteworthy trend surrounding 2012 is the silence about domestic violence/abuse that is relative to the global north. Instead, any mention of domestic violence/abuse is linked to the global south. Again, there is the maintenance of blame on individuals much like 2002, but instead blame is offset to those of more 'atavistic' countries. This glorification of the global north and cynicism toward the global south is mentioned by both Lloyd (2000) and So (2006). The need for the global north to rescue women from 'men of the third world', as So (2006) mentions, highlights the lack of awareness for the prevalence of male hegemony in the global north. The lack of news reporting in 2012 on the domestic violence/abuse that "mail order brides" face in the global north is not backed by the literature; domestic abuse is an immense concern and in Canada specifically, immigrant women, inclusive of "mail order brides", are three to six times more likely to fall victim (Constable 2012; Grosh, 2011; Kusel, 2014; Newsome 2007).

\section{The Narrative of "Choice" in Newspaper Coverage}

Another important aspect of analysis derives from the scholar Merriman (2012) who discussed the idea that "mail order brides" do in fact have a choice. I incorporated the question 'Is becoming a "mail order bride" considered a choice?' as to identify what messages the press is sending out on this issue. In the 2000-2004 period, three news stories stated that becoming a "mail order bride" was a choice, one noted that it was sometimes forced and sometimes a choice and six stories exclaimed that becoming a "mail order bride" was in fact not a choice. The reasons for becoming a "mail order bride" were also analyzed; poverty was given as a reason in 13 news stories, love was present in two news stories and education was mentioned in one. While many news stories commented on poverty, the best description is as follows: “...Canada is a hub in a global industry that recruits poverty-stricken women and children into prostitution, the 
drug trade and mail-order marriages..." (Bell \& Jimenez, 2000, p. A1). The quote from the news story by Bell \& Jimenez (2000) from the National Post correlates with the literature by Lloyd (2000), which makes a connection between sex trafficking and "mail-order" marriages.

In the 2010-2014 period, two of the 10 news stories mentioned that these women do not have a choice in becoming "mail order brides". The remainder of the news stories did not comment on whether or not "mail order brides" choose or do not choose to marry abroad. As well, only four news stories made mention of why these women choose to become "mail order brides"; one news story makes note of poverty, another mentions a combination of poverty and lack of access to education and two other stories mention familial pressures. A news story references a Canadian government fact sheet which outlines that "[p]arents, relatives and communities may use relentless pressure, emotional blackmail, threats... to coerce people to enter marriage" (Curran, 2010, p. A7). In contrast to the 2002 time period, there was overall little commentary on whether "mail order brides" have a choice, nor was there mention of the reasons for their decisions. This is likely because surrounding 2012, governmental focus was to protect against fraudulent marriages (Citizenship and Immigration Canada, 2012), as opposed to the 2002 analysis of the problems "mail order brides" face to provide protection (Belleau, 2003A; Belleau, 2003B; Immigration and Refugee Protection Regulations, 2002).

Through reading the literature on "mail order brides" and maintaining my feminist lens, an option I included as a reason for why these women marry abroad was lack of property rights. While poverty is a valid reason that "mail order brides" seek marriage, it is again interesting that the news stories in both time periods do not question why these women are impoverish; rather than focusing on the catalyst to the poverty, there is focus on simply the result of larger structural issues. This again correlates to the arguments of Grosh (2011) and Kusel (2014) who do not 
focus on structural issues; I argue that there is not enough focus on macro structural issues.

Tweaks to the status quo will not fix the exploitation of these women when the structures of society are laden with gender inequalities.

\section{References to Social/Structural Inequalities}

Surrounding the policy change of 2002, only two news stories out of 22 mentioned the existential inequalities between the "mail order bride" and her husband. Bell (2000A) and Bell (2000B), both from the National Post, explain that "mail order brides" are facing extreme poverty and have no other choice but to seek opportunities abroad for a chance at a better life. These news stories express the exploitation and the lack of power "mail order brides" have in comparison to the husbands. The power imbalances are depicted in the opening sentence of one news story, "Young women from poverty-stricken villages in the Philippines are being lured to Canada by mail-order marriage agencies peddling false dreams...” (Bell, 2000A). As well, a "mail order bride" speaks out and states, "They're just taking advantage of these very innocent people who want to do well" (Bell, 2000B, p. A10). Even surrounding a policy change that promotes protections for "mail order brides", it is interesting that there was minimal mention of inequality between "mail order brides" and their husbands. The aforementioned high prevalence of violence and abuse from this same time frame does not correlate with the apparent minimal prevalence of inequality - especially since $100 \%$ of the violence and abuse was committed against "mail order brides" by their husbands.

Again, despite the aforementioned high prevalence of "mail order bride" abuse, two other categories of analysis did not lead to any findings. I was interested to see if structural inequalities between genders were mentioned, as the abuse and exploitation appears to be grievously onesided; not one of the 22 news stories surrounding the policy change that added protections for 
"mail order brides" mentioned structural gender inequalities. Similarly, there was no mention of patriarchy. After reading numerous news stories from this time period that explain femicide, abuse and men seeking dependent women specifically, the lack of overt mention of patriarchy and structural inequalities is striking.

For the 2010 - 2014 period, there are comparable findings to the 2002 time period. There was again no mention of patriarchy, nor structural gender inequalities. However, in contrast to the 2002 period, surrounding 2012 there was no mention of inequality between "mail order brides" and their husbands. While the 2000-2004 time period made minimal mention of the inequality between "mail order brides" and the husbands, the lack of mention in 2012 correlates with policy objectives. Again, the government was interested in protecting Canada and Canadians from marriage fraud (Citizenship and Immigration Canada, 2012), as opposed to highlighting inequalities between husbands and "mail order brides".

The lack of acknowledgement for inequalities between "mail order bride" and husband does not correlate with scholarly literature. Grosh, (2012), Kusel (2014) and Newsome (2007) explain that immense power imbalances between "mail order brides" and their husbands create inequalities, which are in favour of the husband. As well, surrounding both 2002 and 2012, the lack of attention to the structural inequality between men and women is not in line with the work of Belleau (2003B); she proposes that while power imbalances are present at the individual level, there are also larger inequalities entrenched in society that act to disadvantage women and support men's superior status (Belleau, 2003B).

\section{Conclusion}

The minimal amount of research on the topic of "mail order brides", specifically the lack of Canadian research, called for an exploratory study. There were two time periods of interest, 
surrounding the policy change of 2002 and surrounding the policy change of 2012. While 2002 was to the benefit and protection of "mail order brides" with a reduced sponsorship period (Belleau, 2003A; Belleau, 2003B), 2012 brought associations of fraud and marriages of convenience (Citizenship and Immigration Canada, 2012). Through reading the available literature on "mail order brides", it became evident that this group of immigrant women face heightened dependency and ergo, heightened risk of becoming victims of abuse and violence (Constable 2012; Grosh, 2011; Kusel, 2014; Newsome 2007).

The most recent negative governmental portrayal by Citizenship and Immigration Canada (2012) of "mail order brides" as fraudulent, is troubling when these women actually need more protection. Thus, I wanted to gain information on what newsprint media was sending to the public to see if it was reflective of scholarly research. Surette (2014) expresses that the media, specifically newspapers, shapes public sentiment. Changes to policy can be made through public pressures; however if sentiment is conjured through one-sided media portrayals, helpful policy amendments will not be the end result.

Findings indicate that newsprint portrayals of "mail order brides" surrounding 2002 pushed the need to offer these women more protections. This contrasts the message of protecting against "mail order brides" in 2012. Another important finding that surfaced was the overall use of individual blame in both time periods. Rather than placing blame on the state or global social structures, blame was placed on "mail order brides", husbands, as well as IMBs. This result led to a search for important aspects that were not discussed in the news stories. As a whole there was no mention of patriarchy or broader structural issues that disadvantage and exploit "mail order brides". Coming from a radical feminist lens, the discussions of individualistic blame push for quick fixes as opposed to the revolutionary change needed to end inequalities and male 
hegemony. In terms of policy implications, the removal of conditional residency should be considered. From that point, protections for "mail order brides" can be added. The present policy, introduced in 2012 with conditional residency, is a step toward putting "mail order brides" in more dependant situations, rather than promoting autonomy and providing protection - which is the path we should to move toward.

While my research cultivated important findings, it is not without internal limitation. Obviously, my study does include some personal bias. Effort was made, by the use of my social location, to contextualize my research interests in reference to my lived experiences. In terms of qualitative data specifically, many interpretations can derive from reading the same text (Check \& Schutt, 2012); thus depending on one's social location, data may be interpreted differently. Important aspects of the data may not have been analyzed to their full potential due to my aforementioned bias, however the interest in another theoretical lens may prompt future research. In terms of future research, any input on the topic of "mail order brides" would be an integral addition to existing literature. While noted in my findings and briefly associated with previous scholarly literature, the glorification of the north and demonization of the global south in relation to the "mail order bride" phenomenon requires deeper analysis. This finding appeared in the more recent period of 2010-2014 and it would be useful to tackle the topic with a new theoretical lens. The minimalistic mentions of this issue through authors such as Lloyd (2000) and So (2006), as well as my own research reinforce the need for sole focus on this remerging finding. While my research was mainly exploratory and aimed to identify messages sent out about "mail order brides", further research should move beyond the process and include the voices of women to humanize the discussion. 


\section{Appendices}

\section{A: Coding Manual}

\begin{tabular}{|c|c|}
\hline Theme & Codes \\
\hline Newspaper & $\begin{array}{l}\text { National Post - } 1 \\
\text { Globe and Mail - } 2 \\
\text { Toronto Star - } 3 \\
\text { Toronto Sun - } 4 \\
\text { Vancouver Sun - } 5 \\
\text { Ottawa Citizen - } 6 \\
\text { Montreal Gazette - } 7\end{array}$ \\
\hline Image & $\begin{array}{l}\text { Yes }-1 \\
\text { No }-2\end{array}$ \\
\hline Sex of Journalist & $\begin{array}{l}\text { Male }-1 \\
\text { Female }-2 \\
\text { Other }-3 \\
\text { N/A }-9\end{array}$ \\
\hline National or Local Newspaper & $\begin{array}{l}\text { National }-1 \\
\text { Local }-2\end{array}$ \\
\hline Liberal or Conservative Newspaper & $\begin{array}{l}\text { Liberal }-1 \\
\text { Conservative }-2 \\
\text { Other }-3\end{array}$ \\
\hline Sources Quoted & $\begin{array}{l}\text { Experts/ Researchers }-1 \\
\text { Policy }-2 \\
\text { Opposing Political Party }-3 \\
\text { Government }-4 \\
\text { General Populous }-5 \\
\text { Husbands }-6 \\
\text { "mail order brides" }-7 \\
\text { Other }-8 \\
\text { N/A }-9\end{array}$ \\
\hline Feelings toward Immigration & $\begin{array}{l}\text { For Immigration - } 1 \\
\text { Against Immigration- } 2 \\
\text { Neutral - } 3 \\
\text { N/A - } 9\end{array}$ \\
\hline Discussion of Fraud/Deception & $\begin{array}{l}\text { Yes }-1 \\
\text { No }-2\end{array}$ \\
\hline Language & $\begin{array}{l}\text { Crisis, against "mail order brides" - } 1 \\
\text { Crisis, protections needed for "mail } \\
\text { order brides" - } 2 \\
\text { Non-crisis, against "mail order brides" - } \\
3 \\
\text { Non-crisis, for protecting "mail order } \\
\text { brides" - } 4 \\
\text { Other }-5 \\
\text { N/A - } 9\end{array}$ \\
\hline
\end{tabular}




\begin{tabular}{|c|c|}
\hline Use of 'Traditional' for "mail order brides" & $\begin{array}{l}\text { Yes }-1 \\
\text { No }-2\end{array}$ \\
\hline Export Region of Focus & $\begin{array}{l}\text { China - } 1 \\
\text { Japan - } 2 \\
\text { Former Soviet Union - } 3 \\
\text { Philippines - } 4 \\
\text { South Asia - } 5 \\
\text { Russia - } 6 \\
\text { Other }-7 \\
\text { N/A }-9\end{array}$ \\
\hline Tone toward "MAIL ORDER BRIDE" & $\begin{array}{l}\text { Negative }-1 \\
\text { Positive }-2 \\
\text { Other }-3 \\
\text { N/A }-9\end{array}$ \\
\hline Which individual is blamed? & $\begin{array}{l}\text { "mail order brides" - } 1 \\
\text { Husbands }-2 \\
\text { Immigration Officials }-3 \\
\text { IMBs }-4 \\
\text { Other }-5 \\
\text { N/A }-9\end{array}$ \\
\hline Political Party in Power & $\begin{array}{l}\text { Liberal-1 } \\
\text { Conservative }-2\end{array}$ \\
\hline Mention of Exploitation & $\begin{array}{l}\text { Exploitation of Husbands - } 1 \\
\text { Exploitation of "mail order brides" - } 2 \\
\text { Exploitation of Immigration System- } 3 \\
\text { Other - } 4 \\
\text { N/A - } 9\end{array}$ \\
\hline Tone toward Husband & $\begin{array}{l}\text { Negative }-1 \\
\text { Positive }-2 \\
\text { Other }-3 \\
\text { N/A }-9\end{array}$ \\
\hline Broader Notion of Blame & $\begin{array}{l}\text { Individuals }-1 \\
\text { State }-2 \\
\text { Global Structures }-3 \\
\text { Other }-4 \\
\text { N/A }-9\end{array}$ \\
\hline Are "mail order brides"' voices present? & $\begin{array}{l}\text { Yes }-1 \\
\text { No }-2\end{array}$ \\
\hline How are "mail order brides"' voices presented? & $\begin{array}{l}\text { Vilified }-1 \\
\text { Positively }-2 \\
\text { Neutral }-3 \\
\text { N/A }-9\end{array}$ \\
\hline Mention of 'Human Trafficking' & $\begin{array}{l}\text { Yes }-1 \\
\text { No }-2\end{array}$ \\
\hline How is Human Trafficking applicable? & $\begin{array}{l}\text { Catalyst of the "MAIL ORDER BRIDE" } \\
\text { industry - } 1\end{array}$ \\
\hline
\end{tabular}




\begin{tabular}{|c|c|}
\hline & $\begin{array}{l}\text { Result of the "MAIL ORDER BRIDE" } \\
\text { industry - } 2 \\
\text { Other }-3 \\
\text { N/A }-9\end{array}$ \\
\hline Who is thought to be fraudulent/deceptive? & $\begin{array}{l}\text { Husbands }-1 \\
\text { "mail order brides" }-2 \\
\text { IMBs }-3 \\
\text { Other }-4 \\
\text { N/A }-9\end{array}$ \\
\hline Western women denoted as less 'Traditional' & $\begin{array}{l}\text { Yes }-1 \\
\text { No }-2 \\
\text { N/A }-9\end{array}$ \\
\hline Import Region of Focus & $\begin{array}{l}\text { United States }-1 \\
\text { Canada }-2 \\
\text { Other }-3 \\
\text { N/A }-9\end{array}$ \\
\hline Mention of Policy Flaws & $\begin{array}{l}\text { Yes }-1 \\
\text { No }-2\end{array}$ \\
\hline Which aspect of policy is flawed? & $\begin{array}{l}\text { Sponsorship - } 1 \\
\text { "MAIL ORDER BRIDE" screening - } 2 \\
\text { Husband screening }-3 \\
\text { IMB policies }-4 \\
\text { Other }-5 \\
\text { N/A }-9\end{array}$ \\
\hline Reasons Women Marry Abroad & $\begin{array}{l}\text { Poverty }-1 \\
\text { Lack of Access to Education }-2 \\
\text { Lack of Property Rights }-3 \\
\text { Familial Pressures }-4 \\
\text { Love }-5 \\
\text { Other }-6 \\
\text { N/A }-9\end{array}$ \\
\hline $\begin{array}{l}\text { Is becoming a "MAIL ORDER BRIDE" described as a } \\
\text { choice? }\end{array}$ & $\begin{array}{l}\text { Yes }-1 \\
\text { No }-2 \\
\text { N/A }-9\end{array}$ \\
\hline Mention of Domestic Violence/Abuse & $\begin{array}{l}\text { Yes }-1 \\
\text { No }-2\end{array}$ \\
\hline Mention of IPF & $\begin{array}{l}\text { Yes }-1 \\
\text { No }-2\end{array}$ \\
\hline Who was abused? & $\begin{array}{l}\text { "MAIL ORDER BRIDE" by her Husband - } \\
1 \\
\text { Husband }-2 \\
\text { "MAIL ORDER BRIDE" by her Family - } 3 \\
\text { Other }-4 \\
\text { N/A }-9\end{array}$ \\
\hline Control Tactics used by Husband & $\begin{array}{l}\text { Deportation - } 1 \\
\text { Loss/Inability to gain status }-2\end{array}$ \\
\hline
\end{tabular}




\begin{tabular}{|l|l|}
\hline & Shame -3 \\
& Threats to Life -4 \\
& N/A -9 \\
\hline Is the husband considered educated? & Yes -1 \\
& No -2 \\
& N/A -9 \\
\hline Mention of Patriarchy & Yes -1 \\
& No -2 \\
\hline Mention of Structural Inequality between Genders & Yes -1 \\
& No -2 \\
\hline Mention of Inequality between “mail order bride" & Yes -1 \\
\& Husband & No -2 \\
\hline Control Tactic Used by Family & Shame -1 \\
& Threats to Life -2 \\
& Other -3 \\
& N/A -9 \\
\hline
\end{tabular}




\section{B: Coding Tables}

2000-2004 News Story Data.

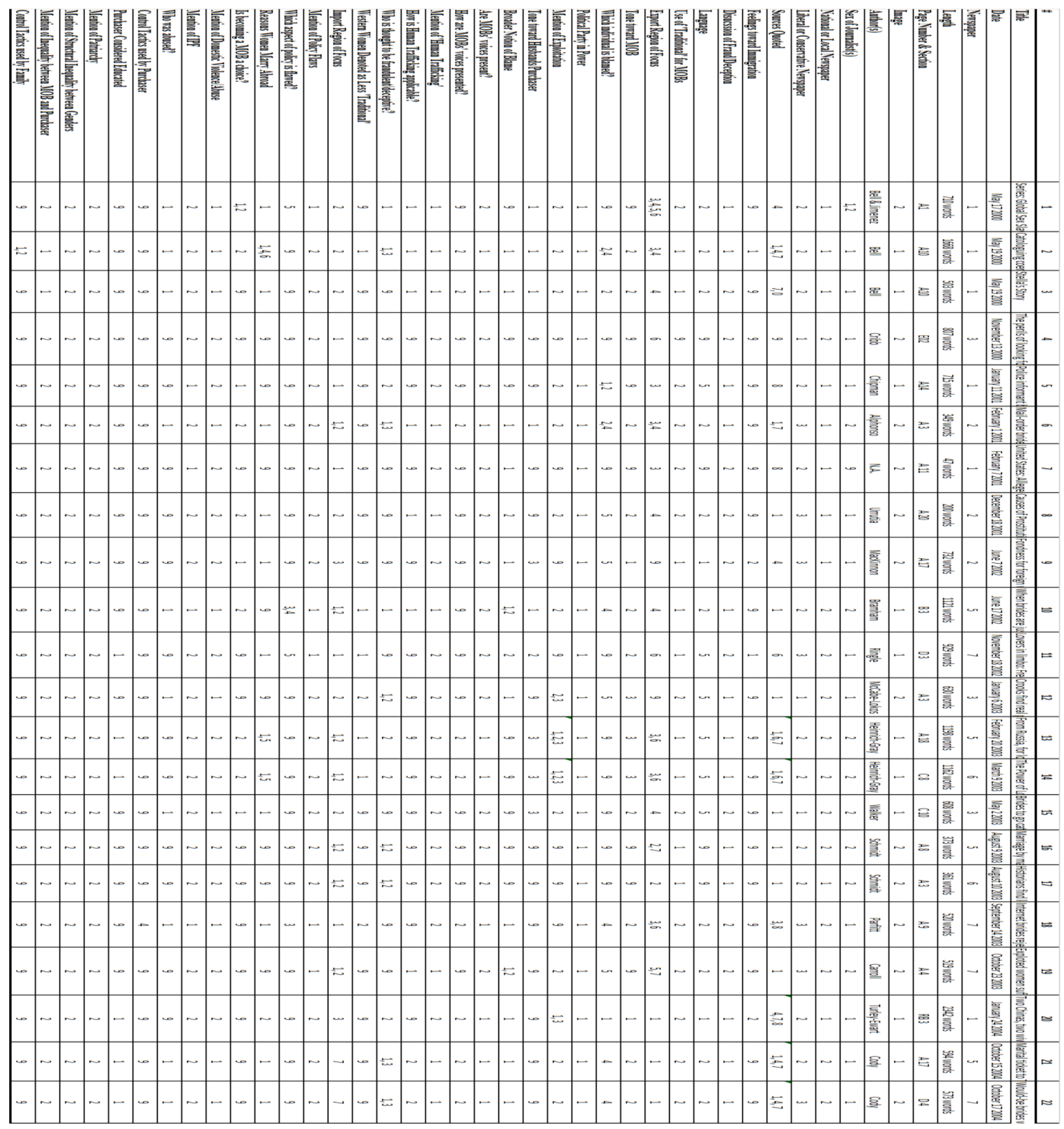


2010-2014 News Story Data.

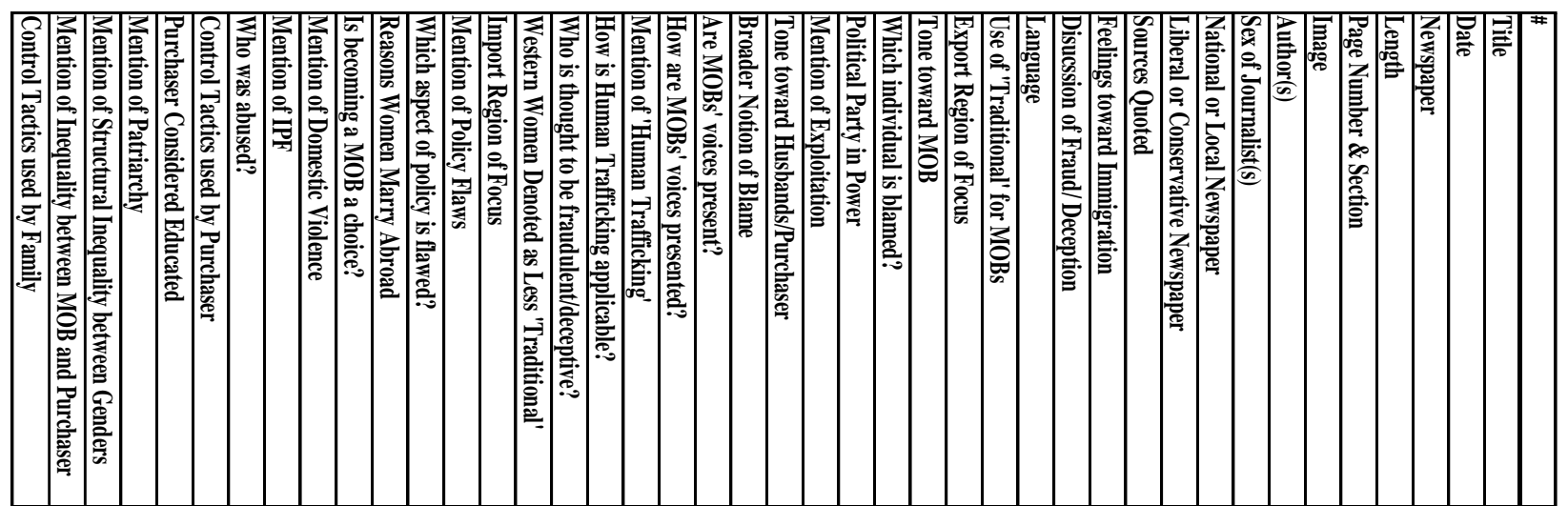

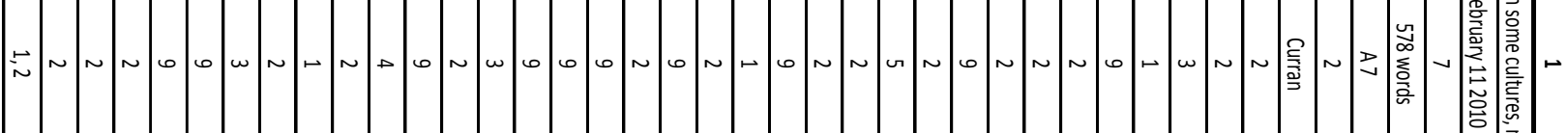

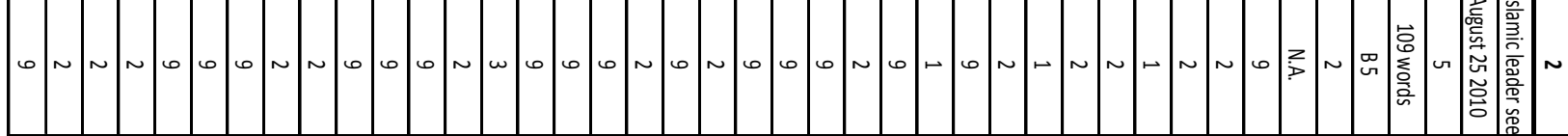

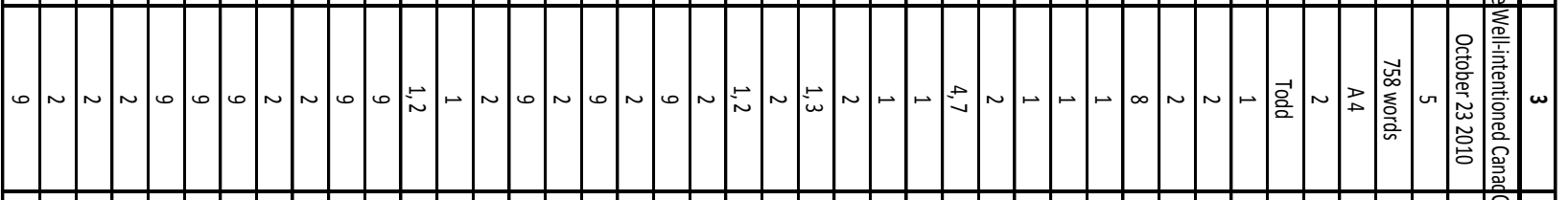

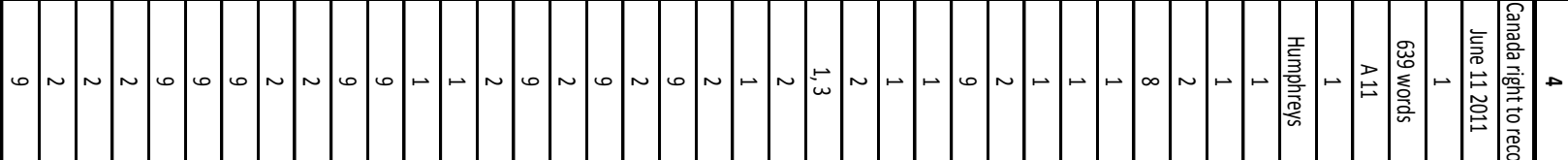

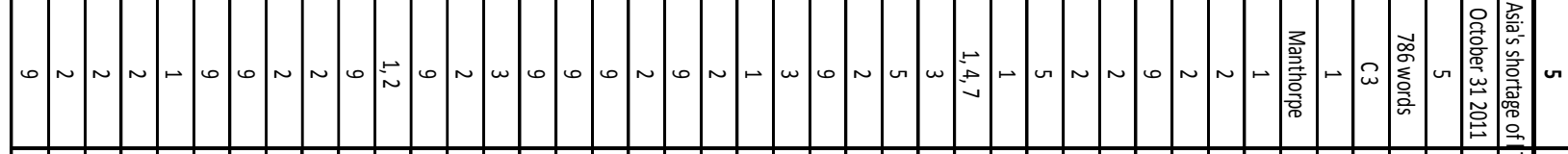

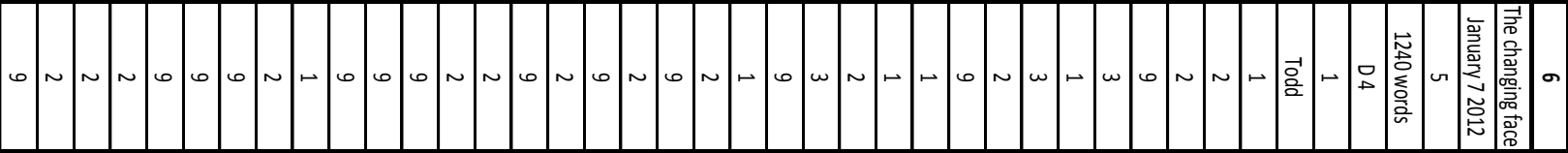

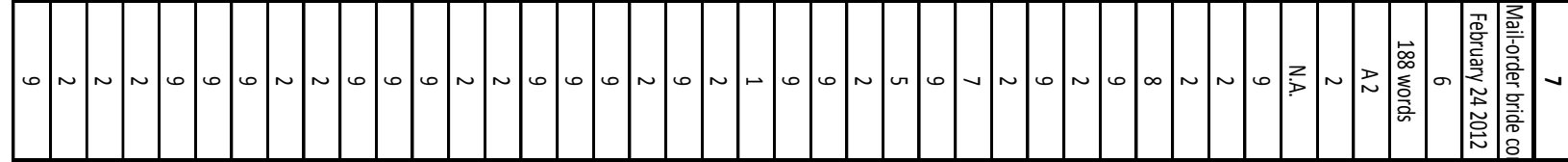

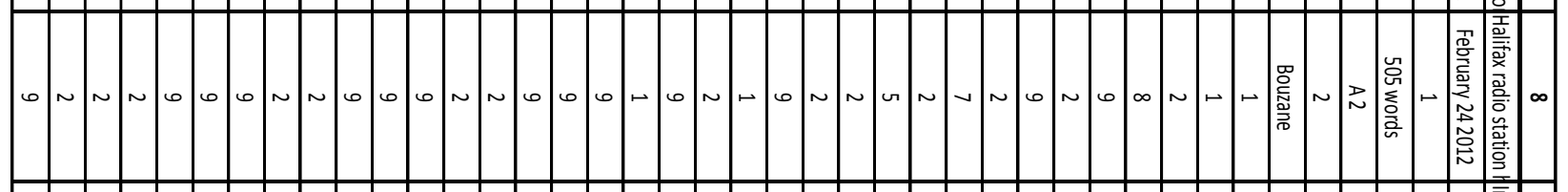

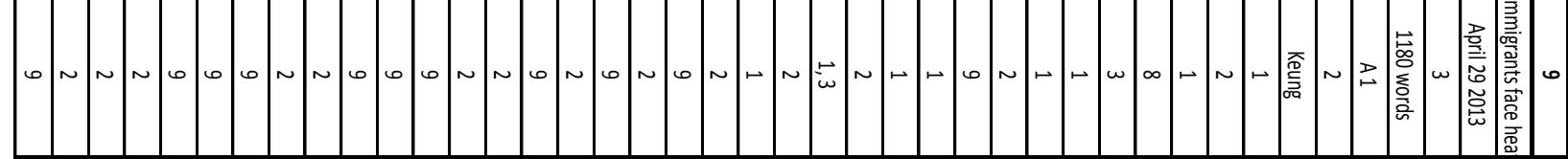

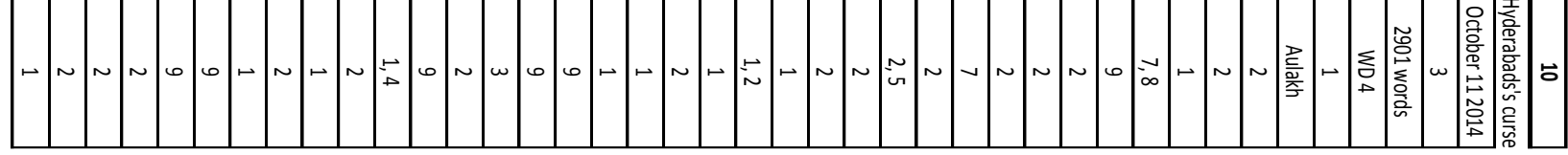




\section{C: News Stories Analyzed}

Alphonso, C. (2001, Feb 01). Mail-order brides a growth industry. The Globe and Mail, p. A3. Retrieved from http://ezproxy.lib.ryerson.ca/login?url=http://search.proquest.com/docview/384282530?a ccountid=13631

Aulakh, R. (2014, Oct 11). 'Hyderabad's curse'. Toronto Star, p. WD4. Retrieved from http://ezproxy.lib.ryerson.ca/login?url=http://search.proquest.com/docview/1609946914? accountid $=1363$

Bell, S. (2000A, May 19). Cataloguing coercion, abuse: Researchers find mail-order brides often are victims of poverty, family pressure and myths of western affluence. National Post, $\mathrm{p}$. A10. Retrieved from http://ezproxy.lib.ryerson.ca/login?url=http://search.proquest.com/docview/329679612?a ccountid $=13631$

Bell, S. (2000B, May 19). Stella's story. National Post, p. A10. Retrieved from http://ezproxy.lib.ryerson.ca/login?url=http://search.proquest.com/docview/329679687?a ccountid $=13631$

Bell, S. \& Jimenez, M. (2000, May 17). Ottawa helpless to stop global sex traffic: Thousands of women and children bought and sold (Toronto edition headline.); Canada a hub for global sex traffickers: Ottawa has no policy to deal with issue (all but Toronto edition headline.) series: Global sex slave industry. National Post, p. A1. Retrieved from http://ezproxy.lib.ryerson.ca/login?url=http://search.proquest.com/docview/329673151?a ccountid $=13631$ 
Bouzane, B. (2012, Feb 24). Halifax radio station holds 'mail-order bride' contest; complaints lodged; no certainty winner will find a spouse, Q104 host says. National Post, p. A2. Retrieved from http://ezproxy.lib.ryerson.ca/login?url=http://search.proquest.com/docview/923551524?a countid=13631

Bramham, D. (2002, Jun 17). When brides are just another export: Mail-order business is unregulated throughout the 'civilized' world. The Vancouver Sun, p. B3. Retrieved from http://ezproxy.lib.ryerson.ca/login?url=http://search.proquest.com/docview/242545508?a ccountid $=13631$

Carroll, A. (2003, Oct 23). Exploited women suffer in silence: Few statistics exist on illegal business. The Gazette, p. A4. Retrieved from http://ezproxy.lib.ryerson.ca/login?url=http://search.proquest.com/docview/433978575?a ccountid $=13631$

Chipman, J. (2001, Jan 11). Police informant becomes a suspect in slaying of Russian mail-order bride: Investigators discover he is also a sex offender. National Post, p. A14. Retrieved from http://ezproxy.lib.ryerson.ca/login?url=http://search.proquest.com/docview/329846967?a countid $=13631$

Cody, E. (2004A, Oct 15). Marital ticket to Taiwan bliss. The Vancouver Sun, p. A17. Retrieved from http://ezproxy.lib.ryerson.ca/login?url=http://search.proquest.com/docview/242316563?a ccountid $=13631$ 
Cody, E. (2004B, Oct 17). Would-be brides wooed to Taiwan: The Gazette, p. D4. Retrieved from http://ezproxy.lib.ryerson.ca/login?url=http://search.proquest.com/docview/434092930?a ccountid=13631

Cribb, R. (2000, Nov 13). The perils of looking for some lovin' online. Toronto Star, p. E2. Retrieved from http://ezproxy.lib.ryerson.ca/login?url=http://search.proquest.com/docview/438201142?a ccountid $=13631$

Curran, P. (2010, Feb 11). In some cultures, not all marriages are made in heaven. The Gazette, p. A7. Retrieved from http://ezproxy.lib.ryerson.ca/login?url=http://search.proquest.com/docview/434897723?a ccountid $=13631$

Heinrich-Gray, K. (2003A, Feb 20). From Russia, for love: The Vancouver Sun, p. A18. Retrieved from http://ezproxy.lib.ryerson.ca/login?url=http://search.proquest.com/docview/242428684?a ccountid $=13631$

Heinrich-Gray, K. (2003B, Mar 09). The (megabyte) power of love: The Ottawa Citizen, p. C8 Retrieved from http://ezproxy.lib.ryerson.ca/login?url=http://search.proquest.com/docview/240632940?a ccountid=13631

Humphreys, A. (2011, Jun 11). Canada right to recoup social assistance. National Post, p. A11. Retrieved from 
http://ezproxy.lib.ryerson.ca/login?url=http://search.proquest.com/docview/871524653?a ccountid=13631

Islamic leader seeks curb on marrying foreigners. (2010, Aug 25). The Vancouver Sun, p. B5. Retrieved from http://ezproxy.lib.ryerson.ca/login?url=http://search.proquest.com/docview/747821411?a ccountid=13631

Keung, N. (2013, Apr 29). Immigrants face heat in marriage fraud crackdown. Toronto Star, p. A1. Retrieved from http://ezproxy.lib.ryerson.ca/login?url=http://search.proquest.com/docview/1346609941? accountid=13631

Mail-order bride contest raises hackles in Nova Scotia. (2012, Feb 24). The Ottawa Citizen, p. A2. Retrieved from http://ezproxy.lib.ryerson.ca/login?url=http://search.proquest.com/docview/923551267?a ccountid $=13631$

McCabe-Lokos, N. (2003, Jan 06). Crooks find real profit in fake papers; preyed-upon pay in cash, sexual slavery or sweatshops from $\$ 5,000$ to $\$ 25,000$ for passports, mail-order brides. Toronto Star, p. A3. Retrieved from http://ezproxy.lib.ryerson.ca/login?url=http://search.proquest.com/docview/438558645?a ccountid=13631

MacKinnon, M. (2002, Jun 07). Fondness for foreign wives alarms UAE. The Globe and Mail (1936-Current), p. A17. Retrieved from http://ezproxy.lib.ryerson.ca/login?url=http://search.proquest.com/docview/1357055646? accountid=13631 
Manthorpe, J. (2011, Oct 31). Asia's shortage of brides stirs social upheaval around region; fewer girl babies and educated women who resist marriage are altering societies. The Vancouver Sun, p. C3. Retrieved from http://ezproxy.lib.ryerson.ca/login?url=http://search.proquest.com/docview/901584044?a countid=13631

Parfitt, T. (2003, Sep 14). Internet brides reject congress safeguard: Law would force screening of suitors. The Gazette, p. A9. Retrieved from http://ezproxy.lib.ryerson.ca/login?url=http://search.proquest.com/docview/433980316?a ccountid=13631

Ringle, K. (2002, Nov 18). Lovers in limbo: Free the fiancées is an internet group devoted to helping mail-order brides get into the U.S. the recent crackdown on immigration has left hundreds of women waiting for visas. The Gazette, p. D3. Retrieved from http://ezproxy.lib.ryerson.ca/login?url=http://search.proquest.com/docview/433878882?a ccountid=13631

Schmidt, S. (2003A, Aug 09). Marriage by mail has four-century Canadian history: The Vancouver Sun, p. A8. Retrieved from http://ezproxy.lib.ryerson.ca/login?url=http://search.proquest.com/docview/242386611?a ccountid $=13631$

Schmidt, S. (2003B, Aug 10). Historians find long-distance courtship a 400-year-old tradition. The Ottawa Citizen, p. A3. Retrieved from http://ezproxy.lib.ryerson.ca/login?url=http://search.proquest.com/docview/240685225?a ccountid $=13631$ 
Todd, D. (2010, Oct 23). Well-intentioned Canada can do more to combat bad-faith marriages of convenience. The Vancouver Sun, p. A4. Retrieved from http://ezproxy.lib.ryerson.ca/login?url=http://search.proquest.com/docview/759847482?a ccountid=13631

Todd, D. (2012, Jan 07). The changing face of Canadian diversity; watch for these five trends to become more present in our thoughts and discussions on how our country should go forward with immigration. The Vancouver Sun, p. D4. Retrieved from http://ezproxy.lib.ryerson.ca/login?url=http://search.proquest.com/docview/914789335?a ccountid=13631

Turley-Ewart, J. (2004, Jan 24). Two Chinas, two wives. National Post, p. RB3. Retrieved from http://ezproxy.lib.ryerson.ca/login?url=http://search.proquest.com/docview/330086611?a ccountid $=13631$

United States: Alleged accomplice charged in murder of mail-order bride. (2001, Feb 07). National Post, p. A11. Retrieved from http://ezproxy.lib.ryerson.ca/login?url=http://search.proquest.com/docview/329898275?a ccountid=13631

Urrutia, M. (2001, Dec 18). Causes of prostitution. The Globe and Mail (1936-Current), p. A20. Retrieved from http://ezproxy.lib.ryerson.ca/login?url=http://search.proquest.com/docview/1125785639? accountid=13631

Walker, S. (2003, May 02). Brides to go catch some bad bouquets. Toronto Star, p. C10. Retrieved from 
http://ezproxy.lib.ryerson.ca/login?url=http://search.proquest.com/docview/438600510?a countid=13631 


\section{References}

Aguilar-Hass, G., Ammar, N., \& Orloff, L. (2006). Battered Immigrants and U.S. Citizen Spouses. Retrieved from https://www.academia.edu/2236701/Battered_Immigrants_and_U.S._Citizen_Spouse S

Alanen, J. (2016). Custom or crime? Catalysts and consequences of forced marriage. American Journal of Family Law, 29(4), 227.

Arat-Koç, S. (1989). In the privacy of our own home: Foreign domestic workers as solution to the crisis in the domestic sphere in Canada. Studies in Political Economy, (28), 33.

Belleau, M. (2003A). Mail-order brides and Canadian immigration policy. Canadian Woman Studies, 22(3/4), 94.

Belleau, M. (2003B). Mail-order brides in a global world. Albany Law Review, 67(2), 595.

Bernstein, E. (2010). Militarized humanitarianism meets carceral feminism: The politics of sex, rights, and freedom in contemporary antitrafficking Campaigns. Signs, 36(1), 4571. doi:1. Retrieved from http://www.jstor.org/stable/10.1086/652918

Chambers, C. (2005). Masculine domination, radical feminism and change. Feminist Theory, 6(3), 325-346. doi:10.1177/1464700105057367

Chaudhuri, S., Morash, M., \& Yingling, J. (2014). Marriage migration, patriarchal bargains, and wife abuse: A study of south Asian women. Violence Against Women, 20(2), 141161. doi:10.1177/1077801214521326

Check, J. \& Schutt, R. (2012). Research Methods in Education. Thousand Oaks, CA: Sage. 
Citizenship and Immigration Canada. (2012). Backgrounder - Conditional Permanent Resident Status. Retrieved from http://www.cic.gc.ca/english/department/media/backgrounders/2012/2012-10-26a.asp Citizenship and Immigration Canada. (2014). Information for Sponsored Spouses or Partners. Retrieved from http://www.cic.gc.ca/english/resources/publications/familysponsorship.asp

Citizenship and Immigration Canada. (2016a). Determine your Eligibility - Sponsor your Spouse, Partner or Child. Retrieved from http://www.cic.gc.ca/english/immigrate/sponsor/spouse-apply-who.asp

Citizenship and Immigration Canada. (2016b). Guide 3900 - Sponsorship of a spouse, common-law partner, conjugal partner or dependent child living outside Canada. Retrieved from http://www.cic.gc.ca/english/information/applications/guides/3900ETOC.asp

Citizenship and Immigration Canada. (2016c). Marriage Fraud. Retrieved from http://www.cic.gc.ca/english/information/protection/fraud/marriage.asp

Connell, R., \& Messerschmidt, J. (2005). Hegemonic masculinity. Gender \& Society, 19(6), 829-859. doi:10.1177/0891243205278639

Consalvo, M. (1998). "3 shot dead in courthouse": Examining news coverage of domestic violence and mail-order brides. Women's Studies in Communication, 21(2), 188.

Constable, N. (2006). Brides, maids and prostitutes: Reflections on the study of 'trafficked' women. Journal of Multidisciplinary International Studies, 3(2), pp. 1-25. 
Constable, N. (2012). International marriage brokers, cross-border marriages and the US anti-trafficking campaign. Journal of Ethnic and Migration Studies, 38(7), 1137. doi:10.1080/1369183X.2012.681457

Elo, S., \& Kyngäs, H. (2008). The qualitative content analysis process. Journal of Advanced Nursing, 62(1), 107-115. doi:10.1111/j.1365-2648.2007.04569.x

Ehrenreich, B. (2005). What is socialist feminism? Monthly Review, 57(3), 70.

Fagan, J., Lyons, S., \& Smyth, B. P. (2014). Content analysis of newspaper reports on alcohol-related deaths. Alcohol and Alcoholism, 49(4), 479-483. doi:10.1093/alcalc/agu015

Giroux, H. A. (2008). Against the Terror of Neoliberalism - Politics Beyond the Age of Greed. Boulder, CO: Paradigm Publishers.

Good, K. R. (2009). Municipalities and multiculturalism: The politics of immigration in Toronto and Vancouver. University of Toronto Press.

Grosh, O. (2011). Foreign wives, domestic violence: U.S. law stigmatizes and fails to protect 'mail-order brides. Hastings Women's Law Journal, 22(1), 81.

Hanna, S. A. (1995). Shared powers: The effects of the shared Canadian federal and Quebec provincial immigration powers on immigrants. Georgetown Immigration Law Journal, 9(1), 75 .

Hodges, K. J. (2010) 'I do’ belong to you: Debating the vulnerability of Filipino mail-order brides in Canada (Master's MRP). Ryerson University, Toronto, Canada.

Holmstrom, N. (2003). The socialist feminist project. Monthly Review, 54(10), 38-48. Retrieved from 
http://ezproxy.lib.ryerson.ca/login?url=http://search.proquest.com/docview/21315731 6 ?accountid=13631

Hsieh, H., \& Shannon, S. (2005). Three approaches to qualitative content analysis. Qualitative Health Research, 15(9), 1277-1288.

Hussein, R. A. (2015). The existing tensions in the defining of human trafficking at a UK and international level: A critical overview. International Journal of Comparative and Applied Criminal Justice, 39(2), 129-138. doi:10.1080/01924036.2014.973051

Immigration and Refugee Protection Regulations (2002), SOR/2002-227.

Kusel, V. I. (2014). Gender disparity, domestic abuse, and the mail-order bride industry. Albany Government Law Review, 7(1), 166.

Kuykendall, K. A. (2012). Selected newspaper coverage of the 2008 California proposition 2: A content analysis (Order No. 1513338). Available from ProQuest Dissertations \& Theses A\&I; ProQuest Dissertations \& Theses Global. (1024286485). Retrieved from http://ezproxy.lib.ryerson.ca/login?url=http://search.proquest.com/docview/10242864 85 ?accountid $=13631$

Langevin, L., \& Belleau, M., (2000). Trafficking in women in Canada: A critical analysis of the legal framework governing immigrant live-in caregivers and mail-order brides. Status of Women Canada. Retrieved from http://publications.gc.ca/collections/Collection/SW2183-2001E.pdf

Levy, J., \& Jakobsson, P. (2013). Abolitionist feminism as patriarchal control: Swedish understandings of prostitution and trafficking. Dialectical Anthropology, 37(2), 333340. doi:10.1007/s10624-013-9309-y 
Liu, M. (2015). Surrogate dating and the translation of gendered meanings across borders: The case of china's E-mail-order brides. Signs, 41(1), 29.

Lloyd, K. A. (2000). Wives for sale: The modern international mail-order bride industry. Northwestern Journal of International Law \& Business, 20(2), 341.

Mackay, F. (2015). Radical feminism. Theory, Culture \& Society, 32(7-8), 332-336. doi:10.1177/0263276415616682

Merriman, J. S. (2012). Holy matrimony plus shipping and handling: A libertarian perspective on the mail-order bride industry. The Independent Review, 17(1), 81 .

Miller, H. E., Thomas, S. L., Robinson, P., \& Daube, M. (2014). How the causes, consequences and solutions for problem gambling are reported in Australian newspapers: A qualitative content analysis. Australian and New Zealand Journal of Public Health, 38(6), 529-535. doi:10.1111/1753-6405.12251

Miteva, N. (2006). Between mail-order brides and turbo-folk women: Eastern Europe's sexualities in transition. New York: The Society for the Scientific Study of Sexuality, Inc.

Narayan, U. (1995). "male-order" brides: Immigrant women, domestic violence and immigration law. Hypatia, 10(1), 104

Newsome, H. B. (2007). Mail dominance: A critical look at the international marriage broker regulation act and its sufficiency in curtailing mail-order bride domestic abuse. Campbell Law Review, 29(2), 291.

Offen, K. (1988). Defining Feminism: A Comparative Historical Approach. Signs, 14(1), 119-157. Retrieved from http://www.jstor.org/stable/3174664 
Rehaag, S. (2011). Do women refugee judges really make a difference?: An empirical analysis of gender and outcomes in Canadian refugee determinations. Canadian Journal of Women and the Law, 23(2), 627-660.

So, C. (2006). Asian mail-order brides, the threat of global capitalism, and the rescue of the U.S. nation-state. Feminist Studies, 32(2), 395-419.

Shon, P. (2012). How to Read Journal Articles in the Social Sciences. Washington, DC: Sage Publishers Ltd.

Soderlund, M. (2007). The role of news media in shaping and transforming the public perception of Mexican immigration and the laws involved. Law \& Psychology Review, 31, 167-177. Retrieved from http://ezproxy.lib.ryerson.ca/login?url=http://search.proquest.com/docview/22934052 7 ?accountid=13631

Surette, R. (2011). Media, Crime, and Criminal Justice. New York, NY: Wadsworth Publishing.

Tahirih Justice Center. (2009). Frequently Asked Questions: International Marriage Broker Regulation Act of 2005. Retrieved from http://www.tahirih.org/wpcontent/uploads/2015/06/IMBRA-Frequently-Asked-Questions.pdf

Tully, S. R. (2007). In the name of love: Modern day mail order brides. Visual Anthropology Review, 23(2), 172-173. doi:10.1525/var.2007.23.2.172

United Nations (2010). Handbook for the Legislation on Violence Against Women. Retrieved from http://www.un.org/womenwatch/daw/vaw/handbook/Handbook\%20for\%20legislatio n\%20on\%20violence\%20against\%20women.pdf 
Vividata. (2015). Newspaper Topline Readership. Retrieved from https://vividata.ca/wpcontent/uploads/2015/10/TOPLINEReadershipbyNewspaperVividata2015-Q2.pdf

Walgrave, S., Soroka, S., \& Nuytemans, M. (2008). The mass media's political agendasetting power. Comparative Political Studies, 41(6), 814-836.

doi: $10.1177 / 0010414006299098$

Wardle, L. D. (2008). From slavery to same-sex marriage: Comity versus public policy in inter-jurisdictional recognition of controversial domestic relations. Brigham Young University Law Review, 2008(6), 1855.

Watson, B. R., \& Riffe, D. (2013). Perceived threat, immigration policy support, and media coverage: Hostile media and presumed influence. International Journal of Public Opinion Research, 25(4), 459-479. doi:10.1093/ijpor/eds032

Worthington, P. (2013, June 3). One of Canada's finest conservative columnists and cofounder of the Toronto Sun, passed away. National Review, 65(10), p.12. Retrieved from http://go.galegroup.com.ezproxy.lib.ryerson.ca/ps/i.do?

Young, J. (2007). The Exclusive Society. Thousand Oaks, CA: Sage Publications.

Zare, B., \& Mendoza, S. L. (2012). 'Mail-order brides' in popular culture: Colonialist representations and absent discourse. International Journal of Cultural Studies, 15(4), $365-381$. 